\title{
Role of microRNAs in response to cadmium chloride in pancreatic ductal adenocarcinoma
}

\author{
Maria Mortoglou ${ }^{1} \cdot$ Aleksandra Buha Djordjevic $^{2} \cdot$ Vladimir Djordjevic $^{3} \cdot$ Hunter Collins $^{4} \cdot$ Lauren York $^{4} \cdot$ \\ Katherine Mani ${ }^{4} \cdot$ Elizabeth Valle $^{4} \cdot$ David Wallace $^{4} \cdot$ Pinar Uysal-Onganer ${ }^{1}$ (I)
}

Received: 7 September 2021 / Accepted: 10 November 2021 / Published online: 14 December 2021

(c) The Author(s) 2021

\begin{abstract}
Pancreatic ductal adenocarcinoma (PDAC) is one of the most fatal and aggressive malignancies with a 5-year survival rate less than $9 \%$. Early detection is particularly difficult due to the lack of symptoms even in advanced stages. microRNAs (miRs/miRNAs) are small ( 18-24 nucleotides), endogenous, non-coding RNAs, which are involved in the pathogenesis of several malignancies including PDAC. Alterations of miR expressions can lead to apoptosis, angiogenesis, and metastasis. The role of environmental pollutants such as cadmium (Cd) in PDAC has been suggested but not fully understood. This study underlines the role of miRs (miR-221, miR-155, miR-126) in response to cadmium chloride $\left(\mathrm{CdCl}_{2}\right)$ in vitro. Lethal concentration (LC50) values for $\mathrm{CdCl}_{2}$ resulted in a toxicity series of AsPC- $1>$ HPNE $>$ BxPC-3 $>$ Panc- $1=$ Panc-10.5. Following the treatment with $\mathrm{CdCl}_{2}$, miR-221 and miR-155 were significantly overexpressed, whereas miR-126 was downregulated. An increase in epithelial-mesenchymal transition (EMT) via the dysregulation of mesenchymal markers such as Wnt-11, E-cadherin, Snail, and Zeb1 was also observed. Hence, this study has provided evidence to suggest that the environmental pollutant $\mathrm{Cd}$ can have a significant role in the development of PDAC, suggesting a significant correlation between miRs and $\mathrm{Cd}$ exposure during PDAC progression. Further studies are needed to investigate the precise role of miRs in PDAC progression as well as the role of $\mathrm{Cd}$ and other environmental pollutants.
\end{abstract}

Keywords Pancreatic ductal adenocarcinoma $\cdot$ Non-coding RNAs $\cdot$ microRNAs $\cdot$ Cadmium $\cdot$ EMT $\cdot$ Apoptosis $\cdot$ LC50

$\begin{array}{ll}\text { Abbreviations } & \\ \text { ADAM9 } & \text { ADAM metallopeptidase domain } 9 \\ \text { CA 19-9 } & \text { Carbohydrate antigen 19-9 } \\ \text { Cd } & \text { Cadmium } \\ \mathrm{CdCl} 2 & \text { Cadmium chloride } 2\end{array}$

Abbreviations

ADAM9

$\mathrm{Cd}$

Cadmium chloride 2

ADAM metallopeptidase domain 9

$\begin{array}{ll}\text { DEVD peptide } & \begin{array}{l}\text { Aspartyl-L-glutamyl-L-valyl-L-aspartic } \\ \text { acid amide }\end{array} \\ \text { EMT } & \text { Epithelial mesenchymal transition } \\ \text { EMT-TFs } & \text { EMT-inducing transcription factors } \\ \text { FBS } & \text { Foetal bovine serum } \\ \text { FOXO1 } & \text { Forkhead box protein O1 }\end{array}$

Pinar Uysal-Onganer

p.onganer@westminster.ac.uk

Maria Mortoglou

w1754188@my.westminster.ac.uk

Aleksandra Buha Djordjevic

aleksandra@pharmacy.bg.ac.rs

Vladimir Djordjevic

vladimir.djordjevic@kcs.ac.rs

Hunter Collins

huntewc@okstate.edu

Lauren York

lauren.york@okstate.edu

Katherine Mani

kmmanis25@gmail.com

\author{
Elizabeth Valle \\ evalle@okstate.edu \\ David Wallace \\ david.wallace@okstate.edu \\ 1 Cancer Research Group, School of Life Sciences, University \\ of Westminster, London W1W 6UW, UK \\ 2 Department of Toxicology, University of Belgrade, \\ 11000 Belgrade, Serbia \\ 3 First Surgical Clinic, Clinical Center of Serbia, Belgrade, \\ Serbia \\ 4 College of Medicine and the Department of Pharmacology \\ and Physiology, Oklahoma State University Center for Health \\ Sciences, 1111 West 17th Street, Tulsa, OK 74107-1898, \\ USA
}




\begin{tabular}{|c|c|}
\hline HPNE & Human pancreatic nestin-expressing \\
\hline HRP & Horseradish peroxidase \\
\hline LC50 & $\begin{array}{l}\text { Lethal concentration } 50 \% \text {; concentration } \\
\text { that will be lethal to half the population } \\
\text { of cells }\end{array}$ \\
\hline MAPK & Mitogen-activated protein kinase \\
\hline microRNAs & MiRs/miRNAs \\
\hline mRNA & Messenger RNA \\
\hline NF- $\kappa \beta$ & $\begin{array}{l}\text { Nuclear factor kappa-light-chain- } \\
\text { enhancer of activated B cells }\end{array}$ \\
\hline P53 & Tumour protein P53 \\
\hline PanIN & Pancreatic intraepithelial neoplasia \\
\hline PARP & Poly (ADP-ribose) polymerase \\
\hline $\mathrm{PCa}$ & Pancreatic cancer \\
\hline PDAC & Pancreatic ductal adenocarcinoma \\
\hline PDGF & Platelet-derived growth factor \\
\hline PTEN & Phosphatase and tensin homolog \\
\hline RPII & RNA polymerase II \\
\hline SD & Standard deviation \\
\hline SIRT1 & Sirtuin 1 \\
\hline STAT3 & $\begin{array}{l}\text { Signal transducer and activator of tran- } \\
\text { scription } 3\end{array}$ \\
\hline TGF- $\beta$ & Transforming growth factor beta \\
\hline TNM & Tumour-node-metastasis \\
\hline UTRs & Untranslated regions \\
\hline
\end{tabular}

\section{Introduction}

PDAC is the deadliest and most prevalent pancreatic cancer (PCa) type, which accounts for $90 \%$ of PCa cases (Von Hoff et al. 2009; Hidalgo et al. 2015). PDAC can be characterized as a "silent killer" and presents the worst prognosis between all cancer types due to the widespread metastasis that patients appear at the time of diagnosis, which is usually in late stages of malignancy (Bortesi et al. 2011). Only a small portion of PDAC patients can benefit from chemotherapy, due to severe toxic effects of the current therapies (Abbruzzese 2008). Especially in advanced stages, the chemotherapeutics options are limited with gemcitabine being the first drug treatment with improvement in the median survival only by a few weeks (Scara et al. 2015; Xu et al. 2015). Carbohydrate antigen 19-9 (CA 19-9) is the most common diagnostic biomarker for PDAC in the last 30 years (Chan et al. 2014); nevertheless, CA 19-9 cannot be characterized as a PDAC-specific biomarker, especially for symptomless patients (Chan et al. 2014).

Interest in the role of $\mathrm{Cd}$ as a toxic metal ubiquitously present in the environment has risen during the last decades, especially with the reference to its possible role in various human diseases, especially carcinomas (Anđelković et al. 2021; Buha et al. 2018, 2019, 2020). Its possible role in PDAC has been recently reviewed by Buha et al. (2017) suggesting multiple mechanisms responsible for $\mathrm{Cd}$ actions leading to the development of PDAC. The three predominant toxic mechanisms proposed are the alterations in the redox status of the cell, changes in the apoptotic pathways, and epigenetic changes. Further research which was a synergy of human observational, experimental, and in vitro studies showed $\mathrm{Cd}$ deposition in pancreatic tissue and revealed $\mathrm{Cd}$-induced disturbances in intrinsic pathway of apoptotic activity and elevated oxidative stress in PDAC cells (Djordjevic et al. 2019). Further studies conducted on PDAC cell lines indicated that the mitochondria may be a site of action for $\mathrm{Cd}$ in promoting tumour development (Wallace et al. 2019). Such findings clearly point towards Cd exposure as an important risk factor for PDAC development.

Preliminary studies suggested a correlation between aberrant expression levels of numerous miRs and PDAC (Yu et al. 2012). miRs, small (18-28 nucleotides-long), endogenous, non-coding, evolutionary conserved, single-stranded RNA molecules, shown to moderate gene expression at the post-transcriptional level through the binding to the complementary sequences of their target messenger RNAs (mRNAs) at the 3' untranslated regions (3' UTRs) (Bartel 2004). Based on the interactions between the $3^{\prime}$ UTRs of mRNAs, miRs can control the expression levels of several genes, while they can also regulate a number of cell signalling pathways, which are related to several malignancies (Lin and Gregory 2015; Meltzer 2005; Słotwiński et al. 2018). Consequently, alterations in miRs expression can have as an outcome, apoptosis, angiogenesis, and metastasis (Amirkhah et at. 2015).

miR-221 is one of the most oncogenic miRs in PDAC alongside miR-21 (Bloomston et al. 2007; Uysal-Onganer et al. 2021; Yang et al. 2016; Zhang et al. 2008), while the overexpression of miR-221 has been correlated to a number of malignancies, such as hepatocellular carcinoma, prostate adenocarcinoma, and colorectal carcinoma (Liu et al. 2014; Tao et al. 2014; Yau et al. 2014; Zheng et al. 2014). Enhanced expression levels of miR-221 are closely associated with platelet-derived growth factor (PDGF)-mediated epidermal-mesenchymal transition phenotype, migration, metastasis, and uncontrolled proliferation of PDAC cells through the inhibition of both mitogen-activated protein kinase (MAPK) and transformation of growth factor $\beta$ (TGF- $\beta$ ) signalling pathways (Masamune et al. 2013; Su et al. 2013; Mortoglou et al. 2021a, b). EMT can be characterized as a key component of the metastatic cascade, which includes the repression of E-cadherin and the activation of genes related to motility and invasion (Kalluri and Weinberg 2009). Therefore, the examination of the most commonly expressed miRs with their related signalling pathways and their associated target genes is crucial for a better understanding of PDAC pathophysiology. Furthermore, upregulation in the expression of miR-155 has been 
also found in PDAC tissue samples (Papaconstantinou et al. 2013). Elevated levels in the expression of miR-155 can result in poor survival in PDAC patients due to the development of fibrogenesis, through TGF- $\beta$ (Greither et al. 2010; Mortoglou et al 2021a,b), while overexpression of this miR has been also associated with an increased progression from pancreatic intraepithelial neoplasia 2 (PanIN-2) to PanIN-3 (Ryan et al. 2014). On the other hand, miR-126 is a tumour suppressor miR, which has been linked to PDAC progression, through the post-transcriptional upregulation of KRAS (Jiao et al. 2012) and HER2 (Garajová et al. 2014). HER2 overexpression is observed in more than $30 \%$ of PDAC cases (Komoto et al. 2009; Mortoglou et al. 2021a,b).

In metastatic process, EMT is responsible for the loss of epithelial cell polarity and cell-cell adhesion (Brabletz et al. 2018; Ye et al. 2017), while studies have shown that miRs are linked to the moderation of EMT, stem cell-like differentiation, invasiveness, migration, and proliferation (Piasecka et al. 2018; Mortoglou et al. 2021a, b). Specifically, EMT is involved in increased tumorigenesis, invasiveness, and metastatic predisposition of several solid tumours including prostate, lung, liver, pancreatic, and breast cancers (Hugo et al. 2007; Lee et al. 2006; Ribatti et al. 2020). In numerous malignancies, EMT can be induced by hypoxia, growth factors regulated by tumour microenvironment, stroma crosstalk, metabolic changes, and innate and adaptive immune responses (Roche 2018).

Wnt-11 is one of the noncanonical Wnt family members, which are activated during carcinogenesis and correlated to a poor prognosis of various cancer types including PDAC (Uysal-Onganer et al. 2010; Arisan et al. 2020; Guo and Wang 2009). During EMT, overexpression of the mesenchymal marker Snail and the decrease of the epithelial marker E-cadherin has been noticed (Lin et al. 2010; Nakamura and Tokura 2011). Particularly, E-cadherin is a protein, which is necessary for the normal epithelial cell maintenance, whereas transcriptional factors including Zeb1 and Snail are highly expressed through the binding in E-cadherin promoter (Felipe Lima et al. 2016; Lamouille et al. 2014; Seton-Rogers 2016; Singh and Settleman 2010). Therefore, transcription factors such as Snail and Zeb1 are key players of EMT (Stemmler et al. 2019). Moreover, EMT is regulated via molecular pathways, which are linked to both oncogenic and tumour suppressor non-coding RNAs, chromatin remodelling, epigenetic and posttranslational modifications, alternative splicing events, and protein stability (De Craene and Berx 2013; Fedele et al. 2017). Wnt-11 overexpression has been observed in PDAC tissues compared to normal adjacent tissues and is associated with tumour-node-metastasis (TNM) staging (Wang et al. 2018a, b). Especially, higher levels of Wnt-11 are correlated to stages II, III, and IV (Wang et al. 2016). On the other hand, Zeb1 upregulation is correlated to advanced PDAC stages and poor malignancy outcome (Arumugam et al. 2009; Buck et al. 2007; Maier et al. 2010). Zeb1 is also responsible not only for the acquisition of an EMT phenotype but also for migration and invasion in response to nuclear factor kappa-light-chainenhancer of activated B cells (NF- $\kappa \beta$ ) signalling in PDAC cells (Maier et al. 2010). Furthermore, downregulation of E-cadherin is associated with poor prognosis and differentiation in PDAC (Iacobuzio-Donahue et al. 2009; Winter et al. 2008), while elevated expression levels of Snail have been found to be related to $80 \%$ of PDAC cases (Hotz et al. 2007). Besides, Snail overexpression is connected to reduced E-cadherin expression, higher tumour grade, and poorly differentiated PDAC cell lines (Hotz et al. 2007).

Recently, mounting evidence has shown that heavy metals, including $\mathrm{Cd}$, might exert their toxicity through miRs (Wallace et al. 2020). Hence, this study aimed to investigate miR expressions in response to $\mathrm{Cd}$ in metastatic PDAC cells. Subsequently, due to the fact that EMT markers could be proven a novel target for anticancer therapy, we also examined the expression levels of Wnt-11, E-cadherin, Snail, and Zeb1 following Cd exposure in PDAC in vitro.

\section{Methodology}

\section{Pancreatic cell cultures and cadmium treatment}

The cell lines are obtained from the American Type Culture Collection (ATCC, Manassas, VA). Control pancreas cells [hTERT-HPNE ("human pancreatic Nestin-expressing" cells or HPNE; ATCC ${ }^{\circledR}$ CRL-4023 $3^{\mathrm{TM}}$, control pancreatic cells)] and tumour [AsPC-1 (ATCC ${ }^{\circledR}$ CRL-1682 ${ }^{\mathrm{TM}}$, pancreatic tumour cells), Panc-1 (ATCC \#CRL-1469' ${ }^{\mathrm{TM}}$, Pancreas ductal epithelioid carcinoma), Panc-10.05 (ATCC \#CRL$2547^{\mathrm{TM}}$, Pancreatic epithelial adenocarcinoma), and BxPC-3 (ATCC \#CRL-1687TM, Pancreatic adenocarcinoma)] were grown and maintained as described in the ATCC-suggested protocols. Unless otherwise specified, cells were grown in their defined optimum growth media. For a parallel set of LC50 assays, cells were grown in a minimal media of MEM plus $1 \%$ foetal bovine serum (FBS). The cells were split in 6-well plates at 3-5 day intervals depending on confluence and cells were grown to $80 \%$ confluency in preparation for 14 days treatment with cadmium chloride $(\mathrm{CdCl} 2 ; 50 \mu \mathrm{M})$, based on our previously published data (Djordjevic et al 2019).

\section{Chemicals and antibodies}

$\mathrm{CdCl}_{2}$, sterile dimethylsulfoxide, sterile phosphate-buffered saline, and molecular grade water were purchased as the highest grade required from Sigma-Aldrich (St. Louis, MO USA), Fisher Scientific (Houston, TX USA), and Pierce 
Biotechnology (Rockford, IL USA). ELISA kits were obtained from Pierce Biotechnology (Rockford, IL USA). Antibodies were obtained from R\&D Systems Inc., (Minneapolis, MN USA), Cell Signaling Technology, Inc. (Danvers, MA USA), and Thermo-Fisher Scientific (Waltham, MA USA). Media for each cell line were obtained from Corning Life Sciences (Tewksbury, MA USA). Media supplements were purchased from Sigma-Aldrich (St. Louis, MO USA), and these included penicillin/streptomycin, glucose, glutamine, and sodium bicarbonate. Foetal bovine serum, triple $0.1 \mu \mathrm{m}$ filtered, was purchased from Atlanta Biologicals through R\&D Systems (Minneapolis, MN USA).

\section{LC50 assays to determine cadmium toxicity after $48 \mathrm{~h}$ exposure}

Each of the five cell lines were plated at an initial density of 20-50,000 cells/well and allowed to adhere for $24 \mathrm{~h}$ prior to the addition of $\mathrm{CdCl}_{2}$. Cells were incubated for $48 \mathrm{~h}$ with increasing concentrations of $\mathrm{CdCl}_{2}$ (12 concentrations, 0-1 mM). After exposure, MTT (3-(4,5-dimethylthiazol2-yl)-2,5-diphenyltetrazolium bromide) stock solutions (11 mM in sterile PBS) were diluted in-well by the addition of $10 \mu \mathrm{L}$ of MTT stock to each well $(1.1 \mathrm{mM}$ final concentration). Plates were returned to the incubator $\left(37^{\circ} \mathrm{C} / 5 \% \mathrm{CO}_{2}\right)$ for $4 \mathrm{~h}$. After incubation, $50 \mu \mathrm{L}$ of DMSO was added to each well to solubilize MTT crystals, and the plates were returned to the incubator for $30 \mathrm{~min}$. Absorbance was measured using a Bio-Tek plate reader at $540 \mathrm{~nm}$ and is directly proportional to the number of live cells.

\section{ELISA assays and protein detection}

The human $\beta$-catenin kit was purchased from MyBioSource, Inc. (MBS266009; San Diego, CA USA), and was designed for measuring $\beta$-catenin from human-derived cells and cell supernatants. Cell preparation and assay protocols were essentially as described in the manufacturer's protocol. The quantity of $\beta$-catenin in the sample extracts was extrapolated from a standard curve using $\beta$-catenin concentrations of $0 \mathrm{pg} / \mathrm{mL}$ to $1000 \mathrm{pg} / \mathrm{mL}$. Cell lysates were prepared after exposure to $\mathrm{Cd}$ for $48 \mathrm{~h}$ by trypsinization, centrifugation, and washing $(3 \mathrm{x})$ in PBS. The resulting cell suspension was subjected to three freeze-thaw cycles at $-20^{\circ} \mathrm{C}$. The suspension was centrifuged at $1000 \times g$ (or 3,000 rpm) for $15 \mathrm{~min}$ at $+2-4{ }^{\circ} \mathrm{C}$ to remove cellular debris. The final supernatant is ready for assay, or can be stored at $-80^{\circ} \mathrm{C}$ until use. The amount of $\beta$-catenin present was quantified using a biotinylated $\beta$-catenin antibody (1:100 dilution).

In-Cell ELISA protocols for the remaining assays were based on the Pierce Biotechnology kit with the antibody either being provided in the kit, or purchased separately. The assay procedures are the same for each. Cells were exposed to $1 \mu \mathrm{M} \mathrm{CdCl}{ }_{2}$ for $48 \mathrm{~h}$ in a $37{ }^{\circ} \mathrm{C} / 5 \% \mathrm{CO}_{2}$ incubator. After incubation, media are removed and $4 \%$ formaldehyde is added to each well to fix the cells. Cells are washed, permeabilized, quenched, and blocked in sequential fashion. The primary antibody is added, and the plated sealed and stored at $+4{ }^{\circ} \mathrm{C}$ overnight. The dilutions of each primary antibody were as follows: phospho-Akt (AF887, R\&D Systems; 1:2000); phosphatase and tensin homolog (PTEN) (AF847, R\&D Systems; 1:1000); Poly (ADP-ribose) polymerase (PARP) (1861790, Thermo-Fisher; 1:1000); Forkhead box protein O1 (FOXO1) (2880S, Cell Signalling; 1:1,000); and tumour protein 53 (p53) (1861777, Thermo-Fisher; 1:1000). Following incubation overnight at $+4{ }^{\circ} \mathrm{C}$, cells are removed, washed and a TMB solution (3,3', 5,5;-tetramethylbenzidine) is added. TMB is a chromogen that can be used in place of horseradish peroxidase (HRP). Absorbance is measured using a Bio-Tek ${ }^{\circledR}$ plate reader and Gen5 software at $450 \mathrm{~nm}$. To standardize the protein expression data, Janus Green whole-cell stain was used to account for potential differences in cell number between wells. Janus Green staining is measured by absorbance at $615 \mathrm{~nm}$. Dividing the absorbance at $450 \mathrm{~nm}$ by the absorbance at $615 \mathrm{~nm}$ yields a relative protein expression.

\section{Caspase 3/7 kinetic assays}

Caspase 3/7 activity (measurement of apoptosis) was determined using the Apo-One ${ }^{\mathrm{TM}}$ Homogeneous caspase-3/7 assay (Promega, Madison WI). Both Caspase 3 and 7 convert the non-fluorescent substrate rhodamine 110, bis(N-CBZL-aspartyl-L-glutamyl-L-valyl-L-aspartic acid amide; Z-DEVD-R110), by removing the DEVD peptides. Removal of the DEVD peptide results in the rhodamine 110 leaving group being excited at a wavelength of $499 \mathrm{~nm}$ with an emission wavelength of $521 \mathrm{~nm}$. The fluorescence generated is directly proportional to the amount of caspase 3 and 7 present. Cells were plated as described above and the treatment was started with the addition of $1 \mu \mathrm{M} \mathrm{CdCl}_{2}$. Plates are returned to the incubator for $48 \mathrm{~h}\left(37^{\circ} \mathrm{C} / 5 \% \mathrm{CO}_{2}\right)$. After $48 \mathrm{~h}$ exposure, caspase $3 / 7$ activity was determined by the addition of $100 \mu \mathrm{L}$ (1:1 with media) of the caspase 3/7 substrate/buffer mix. Plates were wrapped in foil and returned to the incubator $\left(37^{\circ} \mathrm{C} / 5 \% \mathrm{CO}_{2}\right)$ for $1 \mathrm{~h}$. Emitted fluorescence was measured using a Bio-Tek ${ }^{\circledR}$ plate reader and Gen5 software at $485_{\mathrm{ex}} / 530_{\mathrm{em}}$. Additional readings were taken at $3 \mathrm{~h}$ and $6 \mathrm{~h}$ for kinetic assessment of caspase 3/7 activity.

\section{RNA extraction and quantitative real-time PCR}

miR expression levels were assessed in non-treated and treated with $\mathrm{CdCl}_{2}$ Panc-1 and MiaPaCa-2 PDAC cell lines. Panc- 1 and MiaPaCa- 2 cell lines were processed for RNA isolation, followed by cDNA translation and assessment for 
the relative expression of miR-155, miR-221, and miR-126. RNA extraction was carried out using Trizol (Sigma, U.K.), while RNA concentration and purity were measured by NanoDrop Spectrophotometry at $260 \mathrm{~nm}$ and $280 \mathrm{~nm}$ absorbance. Reverse transcription of RNA to cDNA was carried out using the miRCURYâLNAâ RT Kit (Qiagen, U.K.). U6-snRNA was used as reference RNA to normalise miR expression levels. The miRCURYâ LNAâ miRNA SYBRâ Green (Qiagen, U.K.) was used in conjunction with MystiCq microRNA qPCR primers for miR-155 (hsa-miR-155-5p), miR-126 (hsa-miR-126-5p), and miR-221 (hsa-miR-221-5p), which were all obtained from Sigma (U.K.). The sequences for U6-snRNA primers were U6 forward, 5'-GCTTCGGCA GCACATATACTAAAAT- 3 ' and reverse 5'-CGCTTCACG AATTTGCGTGTCAT-3' for both. The conditions for thermocycling were: heat activation at $95{ }^{\circ} \mathrm{C} / 2 \mathrm{~min}$, followed by 40 cycles at denaturation at $95{ }^{\circ} \mathrm{C} / 10 \mathrm{~s}$ and combined annealing/extension at $56^{\circ} \mathrm{C} / 60 \mathrm{~s}$. The miR-155, miR-126, and miR-221 expression levels were normalised to that of U6 using the $2^{\wedge \Delta \Delta C T}$ method. Normal cDNAs were generated using qScriptä cDNA Supermix (Quantabio, UK) with incubations at $22^{\circ} \mathrm{C}$ for $5 \mathrm{~min}, 42^{\circ} \mathrm{C}$ for $30 \mathrm{~min}$, and $85^{\circ} \mathrm{C}$ for $5 \mathrm{~min}$, and the following genes were examined: Wnt-11, E-cadherin, Snail, and Zeb1. PrecisionâPlus qPCR Master Mix (Primer Design, UK) was used for RT-qPCR synthesis with the following thermocycling conditions for 40 cycles; $95{ }^{\circ} \mathrm{C}$ for $2 \mathrm{~min}, 95^{\circ} \mathrm{C}$ for $10 \mathrm{~s}$, and $95^{\circ} \mathrm{C}$ for $60 \mathrm{~s}$. Relative levels of mRNA expression were calculated using the comparative CT/2 $2^{-\Delta \Delta C T}$ method with RNA polymerase II (RPII) as the reference gene.

\section{Statistical analysis}

GraphPad Prism version 9.01 (GraphPad Software, San Diego, U.S.A.) was used for statistical analysis and preparation of graphs. Paired $t$ tests were used to assess the expression levels of selected miRs and proteins compared with the controls. Experiments were carried out in triplicates for miRs and protein analysis. All non-miRNA data were analyzed using GraphPad Prism (v 9.1-9.3; San Diego, CA). Analyses include one-way ANOVA with the specialized Dunnett's test for post hoc comparison to control values. Data analysis was accomplished using a two-way (Cell type $\times$ treatment) or three-way (Cell type $\times$ treatment $\times$ protein) ANOVA with Tukey's test adjusted for multiple comparisons or Sidak's post hoc comparison test, as listed. LC50 values were determined by fitting the data to a nonlinear curve fitting, log concentration $\times$ response (three-parameter) singlesite model, to yield a sigmoid inhibition curve. All data are expressed as the mean \pm standard deviation (SD) of 4-8 assays performed in duplicate or triplicate were indicated. To test for data normality, the D'Agostino-Pearson omnibus test was performed. When the test yielded significant results, the data were deemed to be not normally distributed. For data that violated the assumption of normal distribution, the nonparametric Kruskal-Wallis test was performed, followed by a post hoc comparison using the corrected Dunn's test. Significance is set at $\alpha=0.05$.

\section{Results}

In summary, we determined the LC50 value for $\mathrm{CdCl}_{2}$ in multiple PDAC cell lines. One concern that needed to be addressed was the ability of complete growth media to potentially interfere with the action of the toxic metal. Parallel assays were performed, one in ATCC described growth media and another set in a minimal growth media with only $1 \%$ FBS supplementation and no phenol. Interestingly, we found that there was no media effect in AsPC-1 cells, and the HPNE cells seemed to be more resistant to the lethal effect of $\mathrm{CdCl}_{2}$. The remaining cell lines all responded with increased sensitivity to the lethal effects of $\mathrm{CdCl}_{2}$ significantly lowering the LC50 values in the presence of minimal media. When examining proteins associated with apoptotic processes, there were few $\mathrm{CdCl}_{2}$-related effects, with the many of the differences being related to the cell line, and differences in either basal activity or expression. It may be of interest that in studies examining the expression of phospho-Akt and $\beta$-catenin, tumour cells appeared to respond in the opposite direction as HPNE control cells suggesting the potential for differential responses. We further assessed the expression levels of specific miRs in response to $\mathrm{CdCl}_{2}$ exposure. The current study found that miR-221 and miR155 were upregulated in metastatic PDAC cell lines treated with $\mathrm{CdCl}_{2}$, while miR-126 was downregulated. We have also noted that $\mathrm{CdCl}_{2}$ altered the expression levels of EMT markers such as Wnt-11, E-cadherin, Snail, and Zeb1. Particularly, Wnt-11, Snail and Zeb1 were considerably upregulated following $\mathrm{CdCl}_{2}$ exposure, while E-cadherin expression level was decreased in PDAC cell lines treated with $\mathrm{CdCl}_{2}$ compared to non-treated cells.

\section{LC50 assays to determine cadmium toxicity after $48 \mathrm{~h}$ exposure}

\section{$\mathrm{CdCl}_{2} \mathrm{LC} 50$ analysis in PDAC cells}

Initial LC50 analysis to determine the lethality thresholds was performed in optimum growth media which provides the cells with the required nutrients, and protectants, for optimum growth. Each of the cell lines were incubated with their optimum growth media as defined by ATCC. Cells were allowed to adhere for $24 \mathrm{~h}$ and the exposure was started by the addition of increasing concentrations of $\mathrm{CdCl}_{2}$ and the cells were returned to the 
incubator $\left(37{ }^{\circ} \mathrm{C} / 5 \% \mathrm{CO}_{2}\right)$ for $48 \mathrm{~h}$. We observed a reduction in cell viability with increasing concentrations of $\mathrm{CdCl}_{2}$ (Fig. 1A). The shapes of the curves were best fit to a single-site model (three-parameter model). Between cell lines, there was a clear shift to the left for HPNE and AsPC-1 cells (lower LC50 values), whereas Panc-1, BxPC3, and Panc-10.5 cells were shifted 10-15-fold to the right (Fig. 1B). Kruskal-Wallis analysis revealed a significant difference in LC50 values between cell lines $\mathrm{H}(5)=31.97$; $p<0.0001$. Using Dunn's test for multiple comparisons, control HPNE LC50 values were significantly lower than Panc-1 $(p<0.01)$ and Panc-10.05 $(p<0.01)$. LC50 values for AsPC-1 cells were significantly lower compared

A

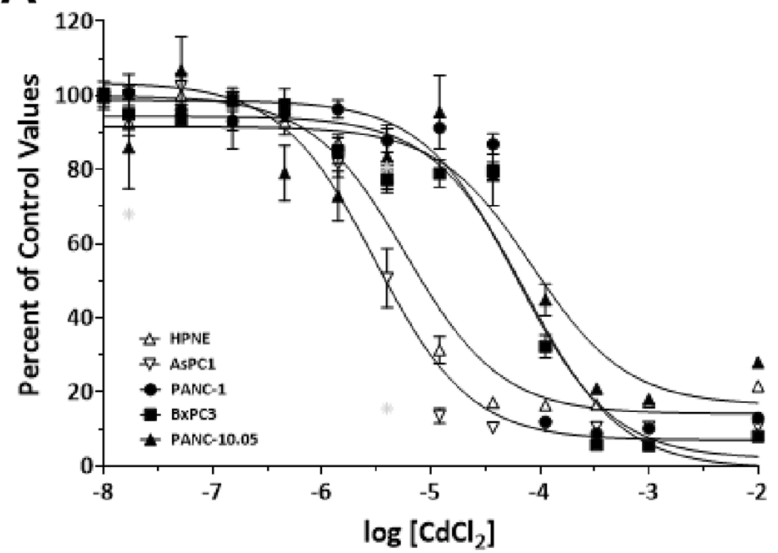

C

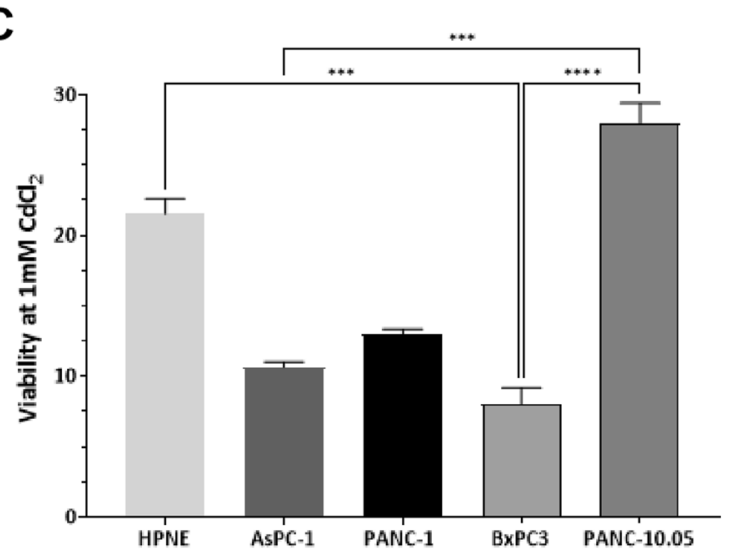

Fig. 1 Comparison of LC50 values in PDAC cells grown in optimum growth media. Exposure to increasing concentrations of $\mathrm{CdCl}_{2}$ resulted in increased lethality in all PDAC cell lines. Cells were plated according to what is outlined in "Methods" and exposed to $\mathrm{CdCl}_{2}$ for $48 \mathrm{~h}$. Live cell numbers were determined by the MTT assay and the data were fit to a nonlinear curve fitting program using a single-site, three-parameter model. The best-fit curve for each of the assays is represented in (A). Individual curves were analyzed and LC50 values obtained to compare group LC50 values (B). When to all other cancer lines, Panc-1 $(p<0.001), \mathrm{BxPC}-3$ $(p<0.05)$, and Panc-10.05 $(p<0.0001)$. The comparisons between LC50 are also in Table1 where the assay media comparison is examined (Table 1). A lethality series can be obtained based on LC50 values, with AsPC- $1 \leq$ HPNE $<$ BxPC- $3<$ Panc- $1=$ Panc-10.05. The maximum lethality at $1 \mathrm{mM} \mathrm{CdCl}{ }_{2}$ was compared across cell lines, and we observed significant differences across cell line $\mathrm{H}(5)=37.22 ; p<0.0001$ (Fig. 1C). PDAC cells were more sensitive to the actions of $\mathrm{CdCl}_{2}$ with AsPC-1, Panc-1, and BxPC-3 cells exhibiting almost $90 \%$ lethality. Control HPNE cells exhibited about $80 \%$ lethality at $1 \mathrm{mM}$ $\mathrm{CdCl}_{2}$, but Panc-10.05 cells were the most resistant with only about $70 \%$ lethality.

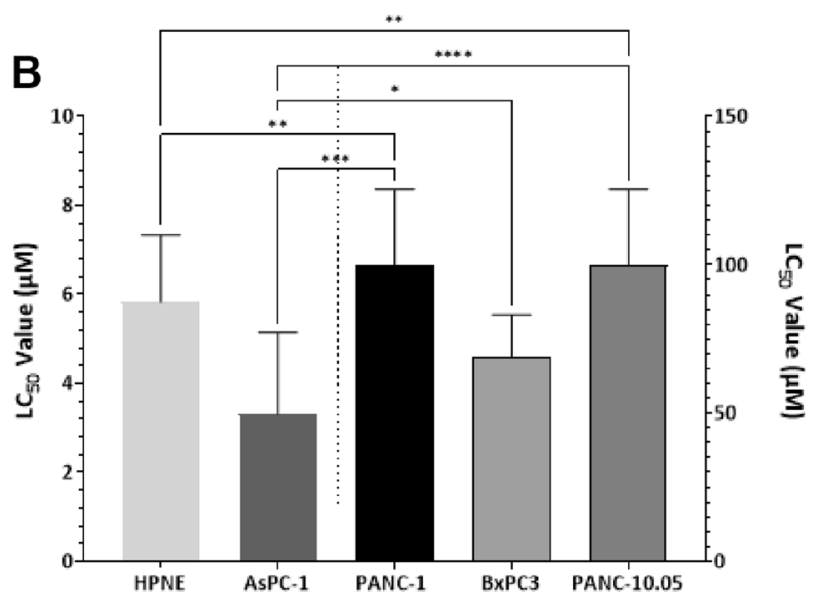

comparing LC50 values, the Panc-1, BxPC-3, and Panc- 0.05 cells are represented on the right axis. Maximum lethality in the presence of $\mathrm{CdCl}_{2}$ occurred at concentrations greater than $1 \mathrm{mM}$. Therefore, (C) represents the maximum lethality of $1 \mathrm{mM} \mathrm{CdCl}_{2}$ in each of the PDAC cell lines. Kruskal-Wallis analysis was used to assess differences in LC50 values between PDAC cell lines and Dunn's test for multiple comparisons. Data represent a mean of eight $(n=8)$ assays performed in duplicate (mean $\pm \mathrm{SD}$ ). Exact $p$ values are indicated (* $p \leq 0.05 ; * * p \leq 0.01 ; * * * p \leq 0.001 ; * * * * p \leq 0.0001)$ 
Table 1 Comparison of LC50 values in ATCC-defined optimum growth media compared to minimal MEM media with $1 \%$ FBS

\begin{tabular}{lll}
\hline & $\begin{array}{l}\text { Cadmium } \mathrm{LC}_{50} \text { values } \\
(\mu \mathrm{M})\end{array}$ & \\
& $\begin{array}{l}{[\mathrm{mean} \pm \mathrm{SD})} \\
\text { Optimum } \\
\text { growth media }\end{array}$ & $\begin{array}{l}\text { Minimal media } \\
(\mathrm{MEM}+1 \% \mathrm{FBS})\end{array}$ \\
\hline HPNE & 5.8 & $36.8^{* *}$ \\
& \pm 1.5 & \pm 5.4 \\
AsPC-1 & 3.3 & 6.0 \\
& \pm 1.8 & \pm 1.9 \\
Panc-1 & 104.0 & $17.7 * * *$ \\
& \pm 24.7 & \pm 3.2 \\
BxPC3 & 69.2 & $12.7 * * *$ \\
& \pm 14.0 & \pm 7.2 \\
Panc-10.05 & 104.1 & $8.9 * * *$ \\
& \pm 24.5 & \pm 1.7 \\
\hline
\end{tabular}

Dunn's test for multiple comparisons was used to assess control HPNE LC50 values compared with the selected PDAC cell lines (AsPC-1, Panc-1, BxPC-3, and Panc-10.05). Exact $p$ values are indicated $(* p \leq 0.05 ; * * p \leq 0.01 ; * * * p \leq 0.001 ; * * * * p \leq 0.0001)$

\section{Effect of minimal media on $\mathrm{CdCl}_{2} \mathrm{LC} 50$ values}

A concern when performing toxicity studies in cell culture is trying to mimic the normal cellular environment as close to normal as possible. The use of optimum growth media provides the cells with the required nutrients, and protectants, for optimum growth. However, it is possible that some of the ingredients of the media can reduce the toxicity observed with environmental toxicants. Our parallel set of assays in a minimal media (MEM $+1 \%$ FBS) with reduced glutamine supplementation, and without phenol, could provide a different environment that would promote toxicity. We observed a reduction in cell viability with increasing concentrations of $\mathrm{CdCl}_{2}$ (Fig. 2A). The shapes of the curves were similar to what was observed in optimum growth media, but the potency of $\mathrm{CdCl}_{2}$ significantly shifted (Fig. 2B). Kruskal-Wallis analysis revealed a significant difference in LC50 values between cell lines $\mathrm{H}(5)=13.54 ; p=0.0089$. Using Dunn's test for multiple comparisons, the only groups that were significantly different were HPNE and AsPC-1 $(p=0.0125)$ cell lines. Interestingly, the potency order between the cell lines was significantly different compared to what was observed in the optimum growth media (Table 1). The maximum lethality at $1 \mathrm{mM} \mathrm{CdCl}{ }_{2}$ was compared across cell lines, and we observed significant differences across cell line $\mathrm{H}(5)=18.29 ; p=0.0011$ (Fig. 2C). PDAC cells were more sensitive to the actions of $\mathrm{CdCl}_{2}$ with both Panc-1 and BxPC-3 cells exhibiting $>90 \%$ lethality. Control HPNE cells were the most resistant with about $75 \%$ lethality at $1 \mathrm{mM} \mathrm{CdCl}_{2}$.

\section{Effect of Cd exposure on caspase 3/7 activity}

We examined the activity of caspase- 3 , a critical executioner caspase, after exposure to $\mathrm{CdCl}_{2}$ for $48 \mathrm{~h}$. The rationale for examining caspase- 3 activity was that they are pivotal for apoptosis and cell death. Normally, caspase- 3 is found in a procaspase form, which is inactive. To activate, either extrinsic factors, death receptor stimulation, or intrinsic, mitochondrial damage, will trigger the activation of caspase-3. Time-course analysis was performed and the ability of caspase-3 to cleave Z-DEVD-NH from rhodamine 110, resulting in a fluorescent signal that is proportional to the amount of caspase- 3 present. Caspase- 7 also recognized the DEVD bond, so the data are expressed as caspase-3/7 activity. We measured the activity of caspase-3/7 at for 1,3 , or $6 \mathrm{~h}$ after a $48 \mathrm{~h}$ exposure to $\mathrm{CdCl}_{2}$ (Fig. 3A).

Expression of cleaved caspase-3 (active caspase) was determined by ELISA (Fig. 3B). There was a significant effect dependent on cell line type for cleaved caspase-3 expression $\left(\mathrm{F}_{4,30}=25.87 ; p<0.0001\right)$. We also observed a significant effect related to $\mathrm{CdCl}_{2}$ exposure across all cell lines $\left(\mathrm{F}_{1,30}=5.288 ; p=0.028\right)$. The trend was for $\mathrm{CdCl}_{2}$ exposure to cause a reduction in expression, with basal expression of cleaved caspase 3 being significantly lower in Panc-1 $(p<0.0001)$ and BxPC-3 $(p=0.0044)$ cells compared to control HPNE cells.

\section{Effect of $\mathrm{Cd}$ exposure on the expression of proteins associated with apoptosis}

We examined the expression of several proteins associated with apoptosis, many of which are implicated in the progression of PDAC. There was a consistent significant main effect across each of the cell lines regardless of the protein that is being examined. Data analysis was carried out using a threeway ANOVA followed by Tukey's multiple comparison post hoc test. Expression of phospho-Akt (Fig. 4A) was clearly different between cell lines $\left(\mathrm{F}_{4,30}=29.84 ; p<0.0001\right)$, Post hoc analysis comparison test demonstrated that control HPNE cell expression of phospho-Akt was significantly higher than the control group in each of the tumour cell lines. PTEN (Fig. 4B) expression was significantly affected by $48 \mathrm{~h}$ exposure to $\mathrm{CdCl}_{2}$ with a significant main effect of both treatment $\left(\mathrm{F}_{1,30}=17.03 ; p=0.0003\right)$ and cell line $\left(\mathrm{F}_{4,30}=106.5 ; p<0.0001\right)$. There was also a significant cross-over interaction $\left(\mathrm{F}_{4,30}=8.12 ; p=0.0001\right)$. The crossover interaction is evident by the slight decline in PTEN expression in the control HPNE cells following $\mathrm{CdCl}_{2}$ exposure, compared to slight increases in PTEN expression across the tumour cell lines. Expression of PARP (Fig. 4C) was only slightly affected by $\mathrm{CdCl}_{2}$ exposure. There was a significant effect of cell line type on PARP expression 

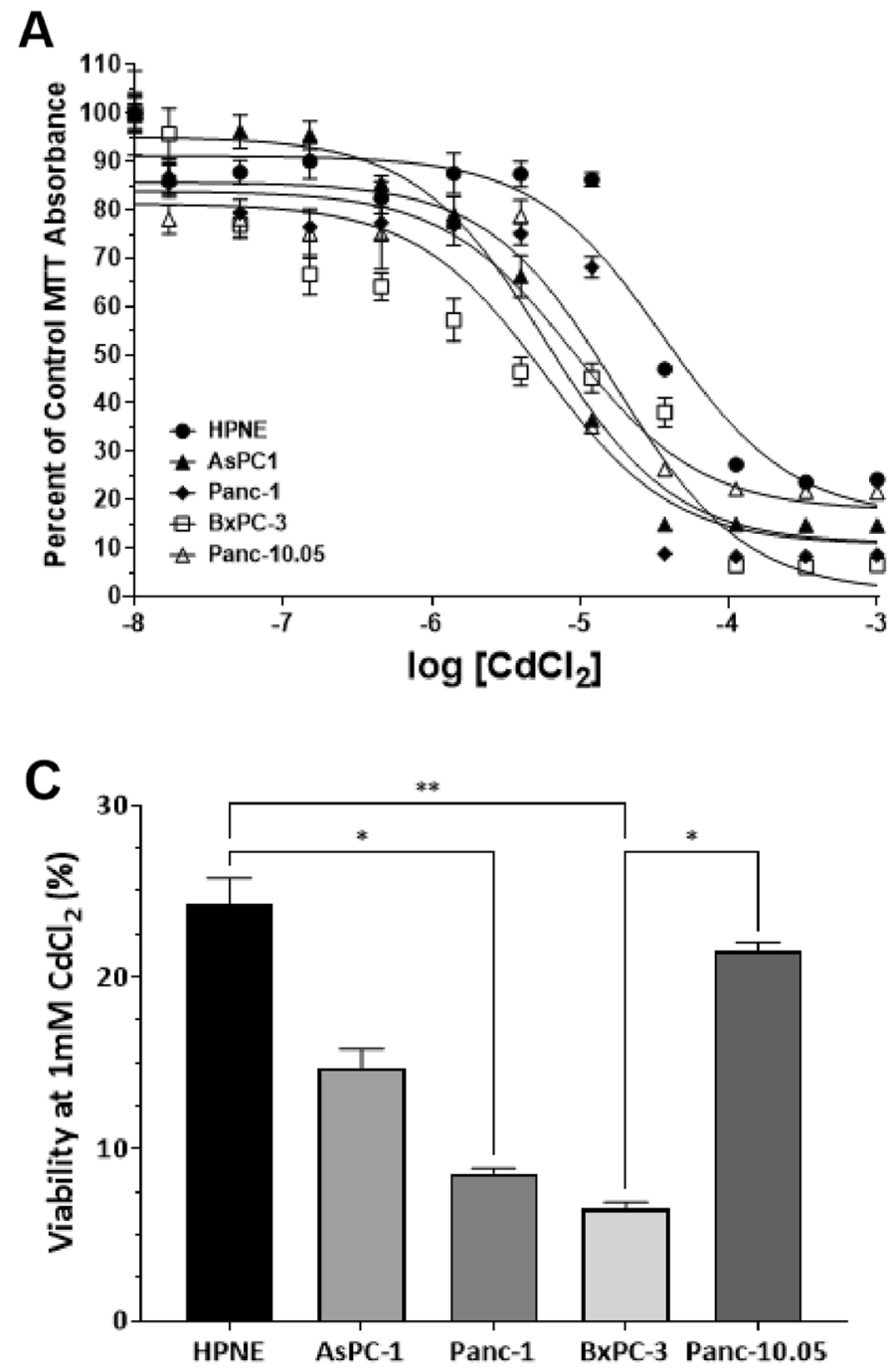

Fig. 2 Comparison of LC50 values in PDAC cells exposed to $\mathrm{CdCl}_{2}$ in minimal (MEM+1\% FBS) media. Exposure to increasing concentrations of $\mathrm{CdCl}_{2}$ resulted in increased lethality in all PDAC cell lines. Cells were plated according to what is outlined in "Methods" and exposed to $\mathrm{CdCl}_{2}$ for $48 \mathrm{~h}$. Live cell numbers were determined by the MTT assay and the data were fit to a nonlinear curve fitting program using a single-site, three-parameter model. The best-fit curve for each of the assays is represented in (A). Individual curves were analyzed and LC50 values obtained to compare group LC50 values (B). Max-

$\left(\mathrm{F}_{4,30}=6.14 ; p=0.001\right)$. There were no differences between control and $\mathrm{CdCl}_{2}$ exposure in any cell line.

For the quantification of $\beta$-catenin, we were able to directly measure the amount of $\beta$-catenin in the cell lysates (Fig. 4D). In control HPNE cells, $\mathrm{CdCl}_{2}$ exposure for $48 \mathrm{~h}$ resulted in a $50 \%$ increase in $\beta$-catenin, but this difference was not significant. We observed a significant effect of cell line type on $\beta$-catenin content $\left(\mathrm{F}_{4,20}=5.94 ; p=0.0026\right)$ with a significant cross-over interaction with treatment $\left(\mathrm{F}_{4,20}=3.1 ; p=0.039\right)$. Generally, tumour cells exhibited a higher basal level of $\beta$-catenin, with AsPC-1 cells

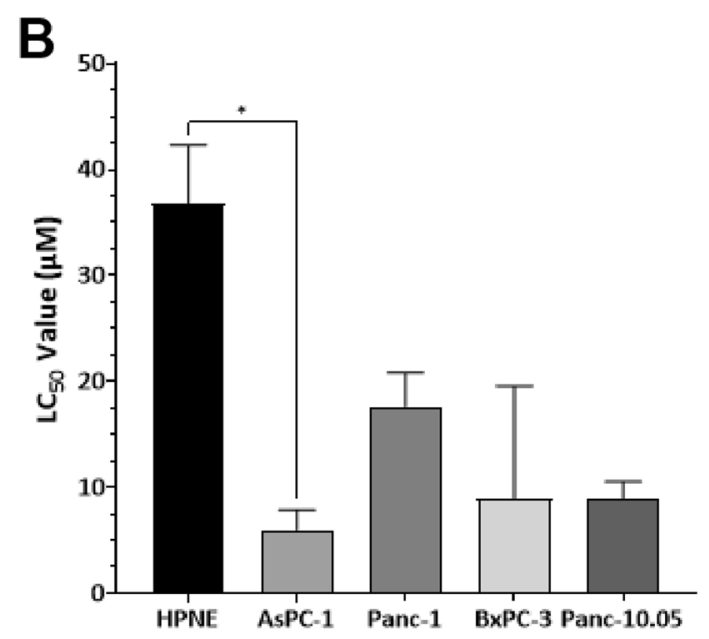

imum lethality in the presence of $\mathrm{CdCl}_{2}$ occurred at concentrations greater than $1 \mathrm{mM}$. Therefore, $(\mathbf{C})$ represents the maximum lethality of $1 \mathrm{mM} \mathrm{CdCl}_{2}$ in each of the PDAC cell lines. Kruskal-Wallis analysis was used to assess differences in LC50 values between PDAC cell lines and Dunn's test for multiple comparisons. The data represent a mean of eight $(n=4)$ assays performed in duplicate (mean \pm SD). Exact $p$ values are indicated $(* p \leq 0.05 ; * * p \leq 0.01 ; * * * p \leq 0.001$; $* * * * p \leq 0.0001)$

demonstrating nearly double the basal level of $\beta$-catenin compared to control HPNE cells $(p=0.0028)$. We examined the effect of $\mathrm{CdCl}_{2}$ exposure on $\mathrm{FOXO} 1$ expression (Fig. 4E) due to the involvement of the FOXO proteins and sirtuin 1 (SIRT1) in glucose handling, development of diabetes, and potential role in the development of PDAC. There was a significant $\left(\mathrm{F}_{4,29}=21.54 ; p<0.0001\right)$ effect of cell line type on the expression of FOXO1 with both BxPC-3 and Panc-10.05 demonstrating a twofold increase compared to control HPNE cells. There was a significant effect of treatment $\left(\mathrm{F}_{1,29}=15.88 ; p=0.0004\right)$ across cell lines with $\mathrm{CdCl}_{2}$ 


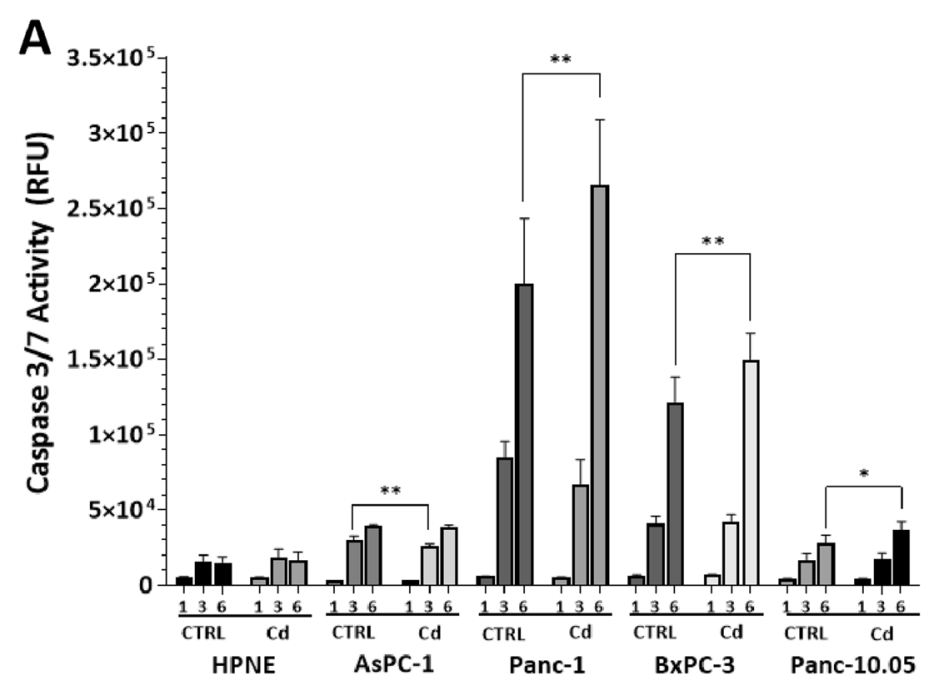

B

Fig. 3 Changes in Caspase 3/7 activity at 1, 3, and $6 \mathrm{~h}(\mathbf{A})$ and the expression of cleaved caspase 3 (B) following $48 \mathrm{~h} \mathrm{CdCl}_{2}$ exposure. After $48 \mathrm{~h}$ exposure, caspase 3/7 activity was determined using the Apo-One ${ }^{\mathrm{TM}}$ Homogeneous caspase-3/7 assay. The fluorescence generated in this kit is directly proportional to the amount of caspase 3 and 7 present. Fluorescence was measured at 1, 3, and $6 \mathrm{~h}$ after the addition of the non-fluorescent substrate (A). Emitted fluorescence of the product was measured using a Bio-Tek ® plate reader and Gen5 software at $499_{\mathrm{ex}} / 521_{\mathrm{em}}$. The amount of cleaved caspase 3 expressed was measured with a modification of the Pierce assay kit. After $48 \mathrm{~h}$ exposure, media were removed and $4 \%$ formaldehyde added to fix the cells in the wells. Primary antibody for cleaved caspase (Invitrogen;

exposure reducing FOXO1 expression, but this change only reached significance in the Panc-10.05 cell line. Finally, we measured the expression of p53 (total) in PDAC cells (Fig. 4F) and observed a significant effect of cell line type on the expression $\left(\mathrm{F}_{4,30}=218.0 ; p<0.0001\right)$. Exposure to $\mathrm{CdCl}_{2}$ had no effect on p53 expression across each of the cell lines. Basal level of p53 expression was significantly elevated compared to HPNE control cells in Panc-1 $(p<0.0001)$, BxPC-3 $(p<0.0001)$, and Panc-10.05 $(p<0.01)$ cells.

\section{MicroRNAs' expression levels are differently modulated in response to cadmium treatments in PDAC cells}

Following the effect of the $\mathrm{CdCl}_{2}$ in apoptosis, we then continued to investigate its role in miR expressions. Based on our previous and others studies, specific miRs including miR-221, miR-155, and miR-126 are closely associated with the development of PDAC in different stages (Greither et al. 2010; Komoto et al. 2009; Su et al. 2013; Uysal-Onganer et al. 2021). Therefore, when assessing miRs expression levels (miR-155, miR-221, miR-126), significant expression changes were observed in response to $\mathrm{CdCl}_{2}$ treatment. Our current study showed that in the Panc-1 cell line, $\mathrm{CdCl}_{2}$ treatment significantly upregulated the mRNA expression
PA5-23921) was diluted 1:1,000, added to the fixed cells, and stored at $+4{ }^{\circ} \mathrm{C}$ overnight. After TMB administration, absorbance was measured at $450 \mathrm{~nm}$. Cells were stained with Janus Green to account for differences in cell number between wells and absorbance read at $615 \mathrm{~nm}$. Dividing the absorbance at $450 \mathrm{~nm}$ by the absorbance at $615 \mathrm{~nm}$ yields a relative protein expression. Two-way ANOVA with Tukey's post hoc analysis was used to examine the expression levels of Caspase 3/7 activity in the selected PDAC cell lines following exposure to $\mathrm{CdCl}_{2}$. The data represent a mean of four $(n=4)$ assays performed in duplicate (mean $\pm \mathrm{SD}$ ). Exact $p$ values are indicated $(*$ $p \leq 0.05 ; * * p \leq 0.01 ; * * * p \leq 0.001 ; * * * * p \leq 0.0001)$

levels of miR-221 by $65 \%(n=3 ; p<0.001$; Fig. $5 \mathrm{~A})$ and miR-155 mRNA expression levels by $30 \%(n=3 ; p<0.05$; Fig. 5B) compared to non-treated PDAC cells (control cells). Expression levels of miR-125 significantly downregulated by $100 \%(n=3 ; p<0.0001 ;$ Fig. $5 \mathrm{C})$ in the same PDAC cell line. Similarly, our results found that in the MiaPaCa- 2 cell line, mRNA expression levels of miR-221 $(n=3 ; p<0.05$; Fig. 5D) and miR-155 ( $n=3 ; p<0.05$; Fig. 5E) were significantly increased by $33.5 \%$ and by $17 \%$, respectively, following $\mathrm{CdCl}_{2}$ exposure, while mRNA expression levels of miR-126 were significantly reduced by $84 \%(n=3$; $p<0.001$; Fig. 5F).

\section{Cadmium treatment differently affects Wnt-11, E-cadherin, Snail, and Zeb1 protein levels in Panc-1 and MiaPaCa-2 cells, following 14 days treatment}

According to our previous and other reports, EMT markers play a significant role in different biological processes such as invasion and metastasis during PDAC development (Arumugam et al. 2009; Dart et al. 2019; Hotz et al. 2007; Iacobuzio-Donahue et al. 2009; Wang et al. 2018a, b). Therefore, based on our previous study, we extensively exposed both Panc-1 and MiaPaCa-2 PDAC cell lines with $\mathrm{CdCl}_{2}$ for 14 days, to further assess the protein levels of Wnt-11, 

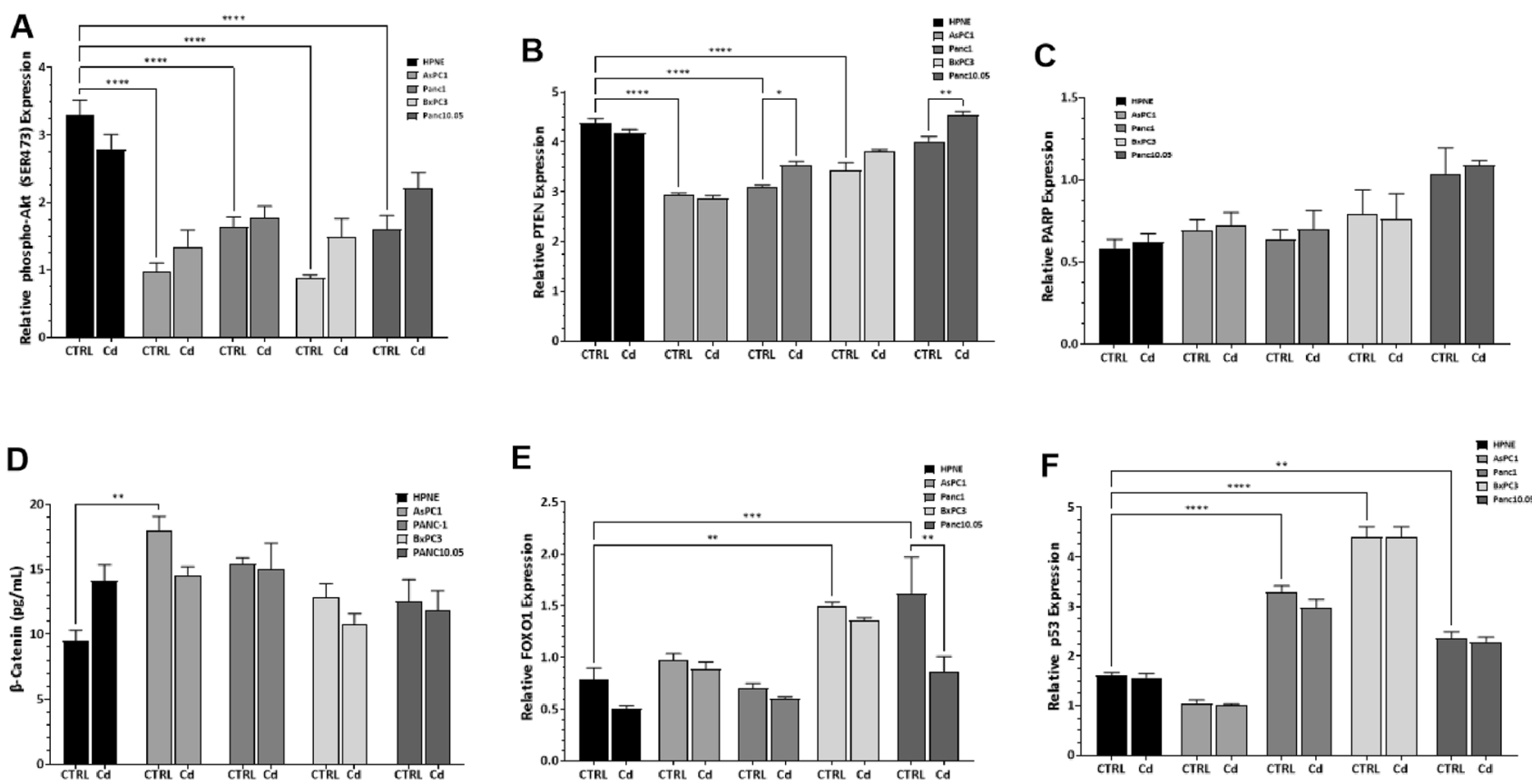

Fig. 4 Changes in protein expression following $48 \mathrm{~h}$ exposure to $\mathrm{CdCl}_{2}$. Proteins associated with cell function and apoptosis were selected and the expression of phospho-Akt (A), PTEN (B), PARP $(\mathbf{C}), \beta$-catenin $(\mathbf{D})$, FOXO1 (E), and total p53 (F) were measured. The amount of cleaved caspase 3 expressed was measured with a modification of the Pierce assay kit as described in 'Methods'. After $48 \mathrm{~h}$ exposure, media were removed and $4 \%$ formaldehyde added to fix the cells in the wells. Primary antibodies were diluted 1:5001:2,000, added to the fixed cells, and stored at $+4{ }^{\circ} \mathrm{C}$ overnight. After TMB administration, absorbance was measured at $450 \mathrm{~nm}$. Cells were stained with Janus Green to account for differences in cell num-

E-cadherin, Snail, and Zeb1 by RT-qPCR (Djordjevic et al. 2019). In our current study, we found that in both PDAC cell lines, $\mathrm{CdCl}_{2}$ significantly upregulated Wnt-11, Snail, and Zeb1 expression levels and considerably reduced E-cadherin protein levels compared to non-treated PDAC cell lines (Fig. 6). Specifically, our results indicated that in the Panc-1 cell line, the mRNA expression levels of Wnt-11\% $(n=3 ; p<0.001$; Fig. 6A), Snail $(n=3 ; p<0.001$; Fig. $6 \mathrm{C})$, and Zeb1 $(n=3 ; p<0.0001$; Fig. $6 \mathrm{D})$ were significantly increased by $47 \%, 38 \%$, and $42 \%$, respectively, following $\mathrm{CdCl}_{2}$ exposure compared with the non-treated Panc- 1 cells (Panc-1 control cells), while mRNA expression levels of E-cadherin $(n=3 ; p<0.0001$; Fig. $6 \mathrm{~B})$ were significantly decreased by $62 \%$ in the same PDAC cell line. Similarly, in the MiaPaCa- 2 cell line, the mRNA expression levels of Wnt-11 ( $n=3 ; p<0.01$; Fig. $6 \mathrm{E})$, Snail $(n=3 ; p<0.01$; Fig. 6G), and Zeb1 $(n=3 ; p<0.0001$; Fig. $6 \mathrm{H})$ were significantly overexpressed by $50 \%, 28 \%$, and $29 \%$, respectively, following $\mathrm{CdCl}_{2}$ exposure compared with the non-treated MiaPaCa- 2 cells (MiaPaCa- 2 control cells), while mRNA expression levels of E-cadherin $(n=3 ; p<0.0001$; Fig. $6 \mathrm{~F})$ ber between wells and the absorbance read at $615 \mathrm{~nm}$. Dividing the absorbance at $450 \mathrm{~nm}$ by the absorbance at $615 \mathrm{~nm}$ yields a relative protein expression. Three-way ANOVA followed by Tukey's multiple comparison post hoc test was used to assess the expression levels of PTEN, PARP, $\beta$-catenin, FOXO1, and $\mathrm{p} 53$ following $48 \mathrm{~h}$ exposure to $\mathrm{CdCl}_{2}$ compared with the non-treated PDAC cells. The data represent a mean of four $(n=4)$ assays performed in duplicate (mean $\pm \mathrm{SD})$. For the $\beta$-catenin assays, the data represent a mean of three $(n=3)$ assays performed in duplicate (mean $\pm \mathrm{SD}$ ). Exact $p$ values are indicated (* $p \leq 0.05 ; * * p \leq 0.01 ; * * * p \leq 0.001 ; * * * * p \leq 0.0001)$

were significantly reduced by $47 \%$ in the same PDAC cell line.

\section{Discussion}

The main outcome of our current study is that there is a strong correlation between $\mathrm{CdCl}_{2}$ exposure, miR expression, and protein expression associated with apoptosis.

Our study has methodically examined the effects of $\mathrm{CdCl}_{2}$ on the expression of multiple proteins associated with apoptotic pathways and as well as the expression of miRs that are involved in the cancer development and changes to apoptotic responses. We observed that $\mathrm{CdCl}_{2}$ exposure for $48 \mathrm{~h}$ exhibited a high degree of lethality on each of the cell lines with LC50 values 3-100 $\mu \mathrm{M}$ in normal growth media. In a reduced, or minimal, media, these values changed to 5-20 $\mu \mathrm{M}$. The maximum lethality in all cell lines ranged from 70 to $85 \%$ at $1 \mathrm{mM} \mathrm{CdCl}_{2}$. We, and others, have shown that $\mathrm{Cd}$ itself is a weak pro-oxidant (Buha et al. 2017; Chen et al. 2011; Liu et al. 2009; Martinez-Zamudio and Ha 2011; 
Fig. $5 \mathrm{CdCl}_{2}$ treatment-mediated effects on miR mRNA expression levels in PDAC cells. (A-C) Effects of $\mathrm{CdCl}_{2}$ exposure in the Panc-1 cell line: (A) miR-221 mRNA expression levels; (B) miR-155 mRNA expression levels; (C) miR-126 mRNA expression levels. (D-F) Effects of $\mathrm{CdCl}_{2}$ exposure in the MiaPaCa-2 cells (D) miR-221 mRNA expression levels; (E) miR-155 mRNA expression levels; (F) miR-126 mRNA expression levels. The column graphic represents the average of three replicates of RNA isolated from each cell line. Data normalised according to RNU6 expression by fold analysis $(n=3, p<0.05)$. Paired $t$ test was used to examine the mRNA expression levels of the selected miRs following $\mathrm{CdCl}_{2}$ treatment compared with the non-treated PDAC cells (control cells).

Exact $p$ values are indicated $(* p \leq 0.05 ; * * p \leq 0.01 ; * * *$ $p \leq 0.001 ; * * * * p \leq 0.0001)$; error bars indicate SD

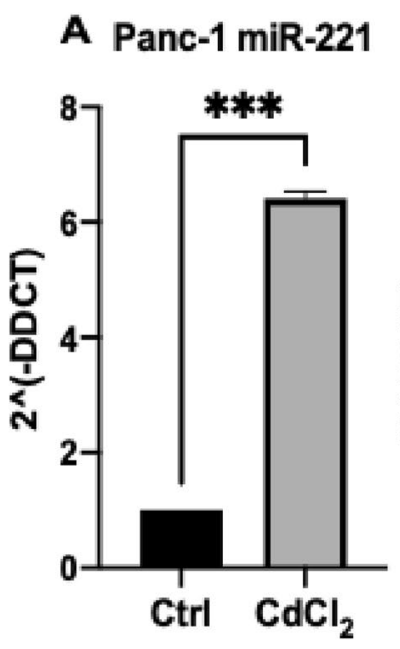

B Panc-1 miR-155
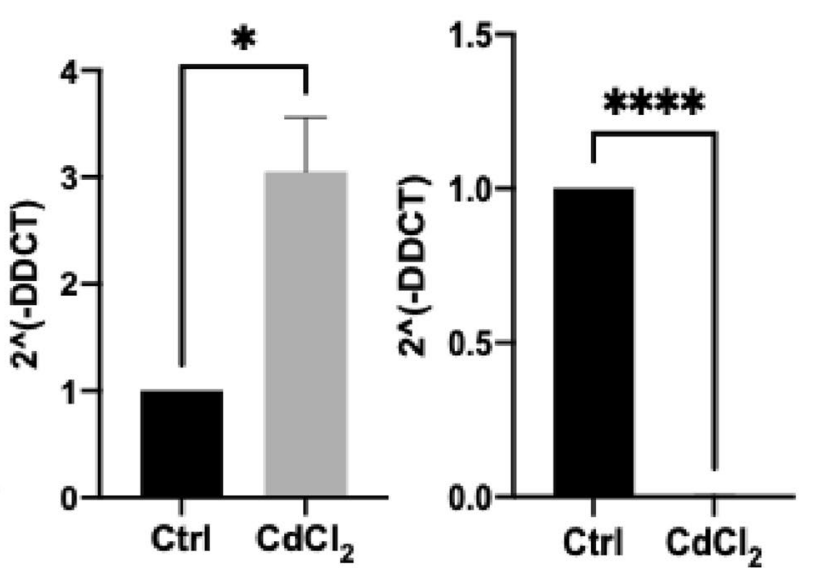

D MiaPaCa-2 miR-221

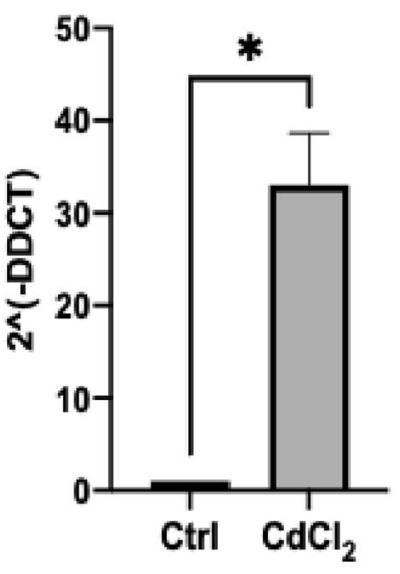

E MiaPaCa-2 miR-155

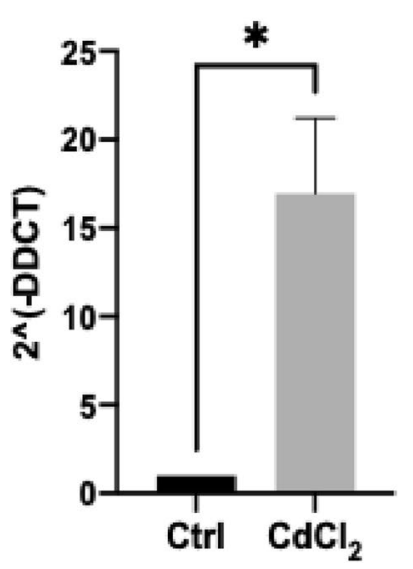

C Panc-1 miR-126

F MiaPaCa-2 miR-126

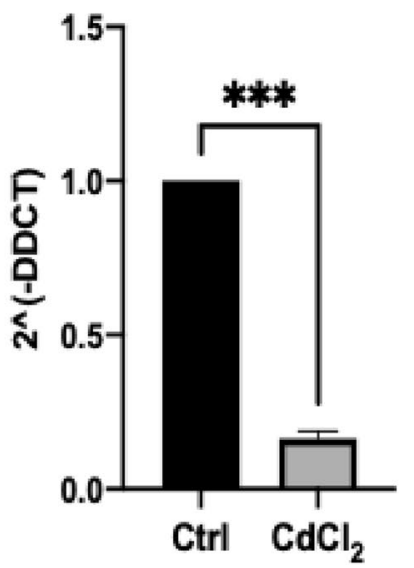

Waisberg et al. 2003; Wallace et al. 2019). The ability to induce oxidative stress would be one mechanism in tumour development. We investigated multiple proteins associated with apoptosis, cell death, cellular repair, and growth regulation. Included in this group was cleaved caspase-3, phosphoAkt, PARP, PTEN, $\beta$-catenin, FOXO1, and p53. The major differences occurred between cell lines, with differing levels of expression. The main $\mathrm{CdCl}_{2}$ effects are observed with PTEN and FOXO1 expression with $\mathrm{CdCl}_{2}$ exposure resulting in increased expression of PTEN in both Panc-1 and Panc-10.05 cell lines. FOXO1 expression in Panc-10.05 was significantly reduced following exposure to $\mathrm{CdCl}_{2}$.

The miRs response in humans after $\mathrm{Cd}$ exposure is very complex, especially having in mind $\mathrm{Cd}$ ability to bioaccumulate in the body. So far, changes in miRs in terms of both up and downregulation were identified in ovarian granulosa cells (Wang et al. 2018a, b), kidneys (Pellegrini et al. 2016), prostate epithelial cells (Ngalame et al. 2016), hepatic cell lines (Urani et al. 2014), and bronchial epithelial cells
(Liu et al. 2015). In our current study, we found that miRs expression levels have been significantly altered in PDAC cells lines treated with $\mathrm{Cd}$ from control cells. In particular, miR-221 and miR-155 expressions were considerably overexpressed in both Panc- 1 and MiaPaca-2 PDAC cell lines treated with $\mathrm{CdCl}_{2}$, while miR-126 was significantly reduced.

As an oncogenic miR, miR-221 has been related to several epithelial cancers such as glioma (Lu et al. 2009; Siegel et al. 2014; Zhang et al. 2009, 2012), prostate carcinoma (Mercatelli et al. 2008), hepatocellular cancer (Gramantieri et al. 2009), and lung cancer (Garofalo et al. 2008), while the upregulation of this miR has been also linked to PDAC cell lines and tumour tissues in comparison to normal pancreatic tissues (Papaconstantinou et al. 2013). Other studies have highlighted that miR-221 not only upregulated in the MiaPaCa-2 cell line compared to normal human pancreatic ductal epithelium (Zhang et al. 2008), but also alterations in its expression levels can promote the metastatic propensity 
A Wnt-11 Panc-1

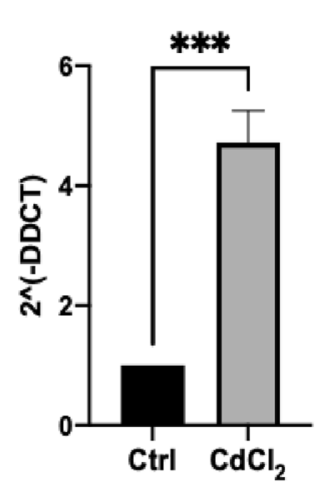

E Wnt-11 MiaPaCa-2

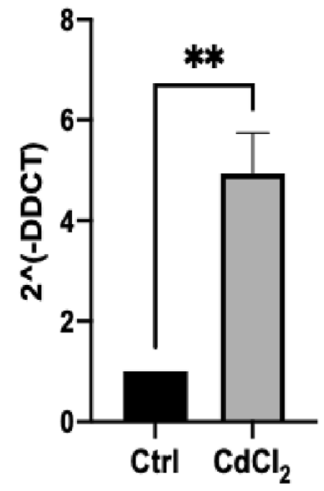

B E-Cadherin Panc-1

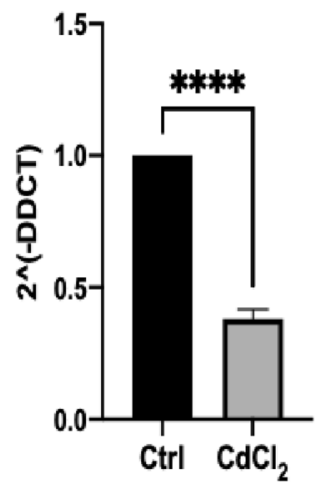

F E-Cadherin MiaPaCa-2

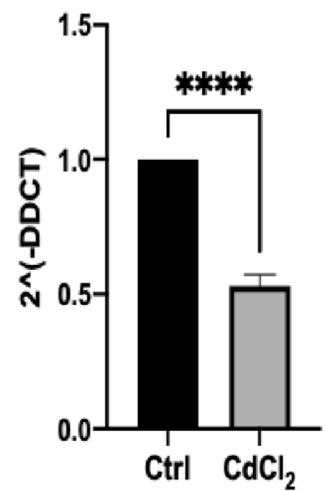

Fig. $6 \mathrm{CdCl}_{2}$ treatment-mediated effects on protein mRNA expression levels in PDAC cells. (A-D) Effects of $\mathrm{CdCl}_{2}$ exposure in the Panc-1 cell line: (A) Wnt-11 mRNA expression levels; (B) E-cadherin mRNA expression levels; (C) Snail mRNA expression levels; (D) Zeb1 mRNA expression levels. (E-G) Effects of $\mathrm{CdCl}_{2}$ exposure in the MiaPaCa-2 cells; (D) Wnt-11 mRNA expression levels; (E) Wnt-11 mRNA expression levels; (F) E-cadherin mRNA expression levels; (G) Snail mRNA expression levels; (H) Zeb1 mRNA expres-

of PDAC cell lines (Xu et al. 2015). According to previous findings, upregulation of miR-221 is common in PDAC tissue samples compared to normal controls and, therefore, the expression of miR-221 in PDAC could be used for the discrimination of PDAC from benign PDAC tissue with specificity $93 \%$ (Bloomston et al. 2007). Importantly, when assessing the expression levels of miR-221 in the current study, miR-221 was identified to be significantly upregulated more in PDAC cells treated with $\mathrm{CdCl}_{2}$ compared with the non-treated PDAC cell, which highlighting that $\mathrm{CdCl}_{2}$ exposure increased the oncogenic property of miR-221 in PDAC cells. miR-155 is a further example of oncogenic $\mathrm{miR}$, which is highly upregulated in several solid malignancies such as breast, colon, and thyroid cancers (Babar et al. 2011; Bakirtzi et al. 2011; Jiao et al. 2012; Nikiforova et al.
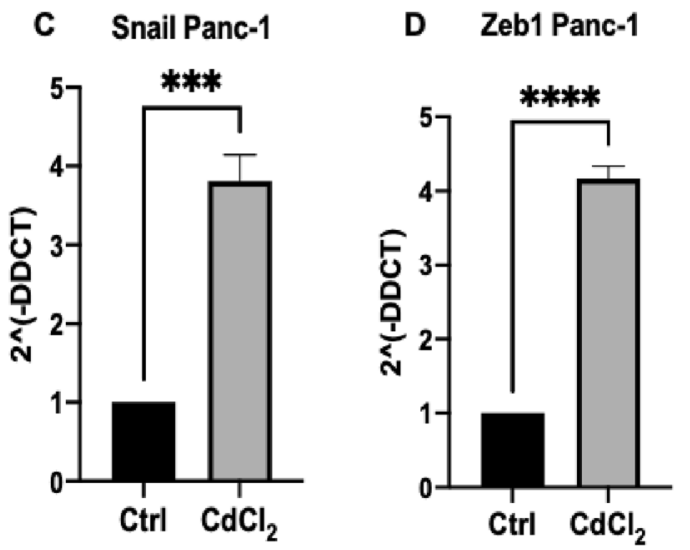

G Snail MiaPaCa-2

H Zeb1 MiaPaCa-2
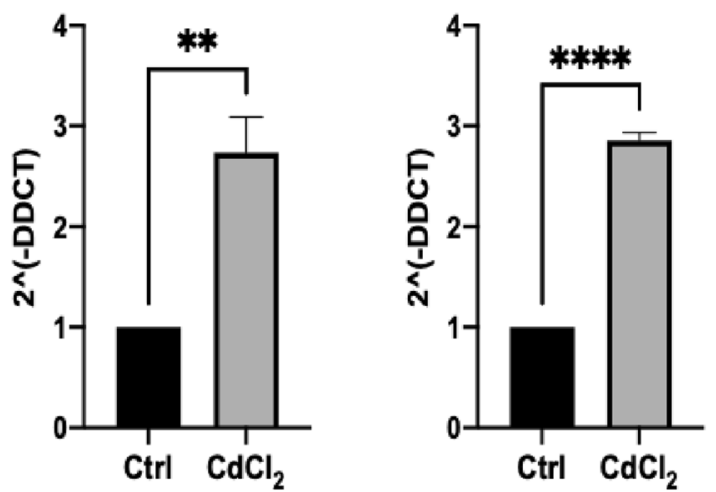

sion levels. The column graphic represents the average of three replicates of RNA isolated from each cell line. Data normalised according to RPII expression by fold analysis $(n=3, p<0.05)$. Paired $t$ tests were used to examine the mRNA expression levels of the selected proteins following $\mathrm{CdCl}_{2}$ treatment compared with the non-treated PDAC cells (control cells). Exact $p$ values are indicated $(* p \leq 0.05$; $* * p \leq 0.01 ; * * * p \leq 0.001 ; * * * * p \leq 0.0001)$; error bars indicate SD

2008). Recent studies have indicated that miR-155 is one of the most oncogenic miR in PDAC (Bloomston et al. 2007; Szafranska et al. 2007), which is linked to poor prognosis of PDAC (Greither et al. 2010). miR-155 upregulation is also associated with PanIN-2 and PanIN-3 lesions compared to healthy pancreatic tissue (Ryu et al. 2010) and its upregulation was noticed in $80 \%$ of early pancreatic lesions (Ryu et al. 2010). In our current study, upregulated expression of miR-155 was found in both Panc- 1 and MiaPaCa- 2 cells treated with $\mathrm{CdCl}_{2}$ compared with the control cells, which indicates a correlation between $\mathrm{CdCl}_{2}$ exposure and the oncogenic capability of miR-155. It has been also reported that the tumour suppressor miR-126 is correlated to numerous malignancies including lung, gastric, breast, and PDAC cancer (Feng et al. 2010; Sempere et al. 2010; Zhou et al. 
2016). Specifically, reduced expression levels of miR-126 can lead to cellular migration and invasion through the inhibition of ADAM metallopeptidase domain 9 (ADAM9) target gene, which is commonly expressed in PDAC (Grutzmann 2004). Therefore, the reduced expression of miR-126 in PDAC has been reported in the previous studies, and this can be also associated with the results of our current study, which showed that mRNA expression levels of miR-126 was significantly decreased following $\mathrm{CdCl}_{2}$ exposure in the Panc- 1 and MiaPaCa- 2 cell lines.

In the current study, we also found that $\mathrm{Cd}$ regulates EMT and dysregulates the expression levels of mesenchymal markers including Wnt-11, E-cadherin, Snail, and Zeb1. Specifically, expression of Wnt-11, Snail, and Zeb1 was significantly overexpressed following the treatment with $\mathrm{CdCl}_{2}$, whereas E-cadherin was reduced in PDAC cell lines treated with $\mathrm{CdCl}_{2}$. miRs can promote not only proliferation and tumourigenesis in PDAC, but also to affect tumour microenvironment (Fathi et al. 2021). Specifically, hypoxia and dysregulations in the expression levels of EMT markers can be altered by several miRs (Lu et al. 2017). Consequently, carcinogenesis can be modulated by certain miRs and signalling cascades including Hedgehog, PTEN/Akt, Wnt, Signal transducer, and activator of transcription 3 (STAT3), ERK, JNK, TGF- $\beta$, and NF-א (Fathi et al. 2021). EMT can be described as a morphologic cellular program, which represents the phenotypic transition from an epithelial to a mesenchymal state that is metastable (Wang et al. 2017). EMT is regulated by numerous complex modulatory networks such as epigenetic alterations, transcriptional control, which comprise EMT-inducing transcription factors (EMT-TFs) as Snail (Zinc finger protein SNAIL), Zeb (Zinc finger E-boxbinding homeobox 1), and transcription regulators including miRs (Wang et al. 2017). Especially, miRs are considered as main regulators of EMT in several cancer types but also as novel early biomarkers in PDAC (Ali et al. 2015; Ballehaninna and Chamberlain 2013; Calatayud et al. 2017; Chang and Kundranda 2017; Dhayat et al. 2015; Gayral et al. 2014; Sethi et al. 2018; Winter et al. 2013). Specifically, miRs can regulate EMT through the control of their target messenger RNAs (mRNA) such as the E-cadherin transcriptional repressor ZEB-1 (Brabletz et al. 2011; Li et al. 2010; Krebs et al. 2017; Tang et al. 2016). For example, miR-200, miR141, miR-200a, miR-200b, miR-200c, miR-429 (Gregory et al. 2008; Humphries and Yang 2015; Mongroo and Rustgi 2010), miR-34a (Ahn et al. 2012; Alemar et al. 2016; Tang et al. 2017), miR-148a (Feng et al. 2016; Peng et al. 2017; Tan et al. 2018, 2017), miR-203a (Jiang et al. 2017; McCubrey et al. 2016; Yang et al. 2017), and miR-655 (Harazono et al. 2013) act as EMT suppressors and negative regulators of metastatic predisposition of PDAC cells (Gregory et al. 2008; Peter et al. 2009), while miR-10b (Ouyang et al. 2014) and miR-197 (Hamada et al. 2013) strongly promote
EMT. Particularly, miR-200 can inhibit the main regulators of EMT such as Zeb1 and Snail, which further results in the overexpression of E-cadherin levels (Gregory et al. 2008; Peter et al. 2009). Moreover, upregulation of miR-200c is linked not only to E-cadherin expression in resected human pancreatic tumour samples but also in better survival rates in comparison to patients with reduced miR-200c levels (Yu et al. 2010). Furthermore, Zeb1 can also suppress miR-200c and miR-141 transcription, which further contributes to the differentiation state of PDAC cells (Burk et al. 2008). Furthermore, miR-200 family can also inhibit Notch signalling, which is responsible for tissue homeostasis and is closely linked to EMT through the overexpression of Notch signalling and Zeb1 and decrease of miR-200 family in PDAC (Brabletz et al. 2011). A previous study showed that Zeb1 is a key target of miR-655, which is an EMT-suppressor $\mathrm{miR}$ that is correlated to favorable overall survival in PDAC patients (Harazono et al. 2013). Ahn et al., (2012) also indicated that miR-34a acts as a target of ZEB-1, which leads to the reduction of invasion and metastasis.

The downregulation of E-cadherin in PDAC patients has been widely described by the previous studies, which suggested that the loss of E-cadherin expression is detected in $43 \%$ of PDAC patients and associated with poor outcome and increased invasion and aggressiveness (Hong et al. 2011). The results of this study showed that the mRNA expression levels of E-cadherin were significantly reduced following the exposure of PDAC cells to $\mathrm{CdCl} 2$, which points out the importance of assessing the role of $\mathrm{CdCl} 2$ in EMT pathways during PDAC progression. Importantly, recent studies have suggested that Zeb1 and Snail overexpression is closely associated with PDAC progression and especially with inhibition of apoptosis and chemoresistance against gemcitabine in PDAC (Li et al. 2009; Vega et al. 2004; Yin et al. 2007). Based on this information, the results of the current study, which showed a significant upregulation of these EMT markers following $\mathrm{CdCl}_{2}$ exposure in PDAC cells, indicate the importance of $\mathrm{CdCl}_{2}$ in the regulation of these key tumourogenic PDAC EMT proteins. Additionally, other reports showed that Wnt-11 can enhance EMT, aggressiveness and migration in PDAC, which further affects the survival rates in PDAC patients (Dart et al. 2019). Specifically, Wnt-11 downregulation can promote not only EMT but also the expression levels of neuronal and stemness markers, which are linked to metastasis (Dart et al. 2019). In our current study, we particularly found that the mRNA expression levels of Wnt-11 were significantly overexpressed in Panc-1 and MiaPaCa-2 cells treated with $\mathrm{CdCl}_{2}$ compared to the control cells; which promote pilot insights into the role of $\mathrm{CdCl}_{2}$ in the Wnt-11 pathways. Conclusively, the Wnt family has been considered to be associated with TNM staging and especially with early stages of PDAC progression (Dart et al. 2019; Wang et al. 2018a, b; 
Wang et al. 2016), and plays a crucial role as regulator of stemness, EMT, and invasiveness of several cancer types comprising PDAC (Dart et al. 2019; Murillo-Garzón et al. 2018; Wei et al. 2014).

The existing evidence is clear, exposure to $\mathrm{CdCl}_{2}$, results in cellular damage that can lead to the development of PDAC. We have observed cellular effects consistent with changes in the expression of select miRs that are involved in tumour development. We have also observed changes in protein expression that may contribute to PDAC formation. Normal pancreatic function is maintained by normal functioning of various miRs. Multiple miRs have important roles in normal insulin function and sensitivity, diabetes, and PDAC development (Chakraborty et al. 2013). Examining the different pathways and potential overlap between cellular signalling mechanisms, relationships between miRs/gene/ protein expression become evident. FOXO1 has been shown to inhibit the growth of tumours and can promote apoptosis (Mou et al. 2017). This is interesting considering $\mathrm{CdCl}_{2}$ exposure tended to reduce FOXO1 expression which would result in tumour growth. Data have shown that FOXO1, and other forkhead box transcription proteins, can increase the expression of pro-apoptotic genes and interfere with pathways utilizing $\mathrm{Wnt} / \beta$-catenin, Akt, and PTEN, and is indirectly regulated by miR-221 (Lima et al. 2011; Mou et al. 2017). In breast cancer, miR-221 can work through both modulating the estrogen receptor gene, and FOXO1 expression (Mou et al. 2017). miR-221 regulates a target, Dickkopf 2 , subsequently inhibiting the activation of the Wnt/ $\beta$ catenin pathways (Chen et al. 2020). An inverse relationship between miR-221 and FOXO1 (downregulation of miR-221/ upregulation of FOXO1) has been reported in ovarian cells in menopause (Wei et al. 2021). Overexpression of miR-221 can directly increase the growth and proliferation of PDAC cells by downregulating PTEN expression and upregulating phospho-Akt expression (Yang et al. 2016). The upregulation of miR-221 observed in our study did not translate to a reduction in PTEN and an increase in phospho-Akt. The tumour cell lines did show a slight increase in phospho-Akt expression following $\mathrm{CdCl}_{2}$ exposure, but no downregulation of PTEN expression. Downregulation of miR-221 will result in an increased expression of PTEN, as well as p27, p57, and PUMA which inhibits the growth and proliferation of PDAC cells (Park et al. 2009; Sarkar et al. 2013; Song et al. 2019). The regulation of p53 involves both positive and negative regulation, and the ability of p53 to regulate the expression of other miRs. Key miRs involved with p53 function are miR-34, miR-29, and miR-125 (Lima et al. 2011). Khakinezhad-Tehrani et al. (2021) reported that when miR221 was suppressed, pro-apoptotic proteins such as p53 were overexpressed and the tumour suppressor, miR-34, was also overexpressed. The miR-221-mediated changes in p53 and miR-34 expression could then interact with FOXO protein expression and SIRT1 activity. p53 can stimulate miR-29, which inhibits PI3K and reducing expression and activity of Akt (Otsuka and Ochiya 2014). P53 directly and indirectly interacts with SIRT1 via miR-34, while SIRT1 can interact with FOXO proteins (Otsuka and Ochiya 2014; Yamakuchi 2012).

\section{Conclusion}

PDAC is the most fatal malignancy, and therefore, it is crucial to develop a significant body of knowledge in the field of PDAC carcinogenesis. The role of environmental pollutants, such as $\mathrm{Cd}$, in PDAC have been suggested but still not fully understood. This is the first research to indicate the role of miRs in response to $\mathrm{Cd}$ in PDAC, suggesting a significant correlation between miRs and $\mathrm{Cd}$ exposure during PDAC progression. These studies have also begun to establish a connection between apoptotic protein regulation, miRs, and Cd exposure in PDAC. Further studies are needed to investigate the precise role of miRs in PDAC progression as well as the role of $\mathrm{Cd}$ and other environmental pollutants in such processes. Furthermore, epigenetic data should be incorporated into risk assessments for $\mathrm{Cd}$ exposures improving our ability to predict outcomes and define more efficient prevention measures.

Funding Oklahoma State University Center for Health Sciences (OVPR) Pilot/Seed Grant (AG154391) D.R.W., University of Westminster, School of Life Sciences Research Enhancement Grant 2020 P.U.O (ALS90); University of Westminster SLS PhD Studentship M.M.

Code availability Not applicable.

\section{Declarations}

Conflict of interest The authors declare there are no conflicts of interest or competing interestings.

Ethical approval Not applicable.

Ethical Standards The manuscript does not contain clinical studies or patient data.

Consent to participate Not applicable.

Consent for publication All authors reviewed and approved the final manuscript.

Open Access This article is licensed under a Creative Commons Attribution 4.0 International License, which permits use, sharing, adaptation, distribution and reproduction in any medium or format, as long as you give appropriate credit to the original author(s) and the source, provide a link to the Creative Commons licence, and indicate if changes were made. The images or other third party material in this article are 
included in the article's Creative Commons licence, unless indicated otherwise in a credit line to the material. If material is not included in the article's Creative Commons licence and your intended use is not permitted by statutory regulation or exceeds the permitted use, you will need to obtain permission directly from the copyright holder. To view a copy of this licence, visit http://creativecommons.org/licenses/by/4.0/.

\section{References}

Abbruzzese JL (2008) Adjuvant therapy for surgically resected pancreatic adenocarcinoma. JAMA 299(9):1066-1067. https://doi.org/ 10.1001/jama.299.9.1066

Ahn YH, Gibbons DL, Chakravarti D, Creighton CJ, Rizvi ZH, Adams HP, Pertsemlidis A, Gregory PA, Wright JA, Goodall GJ et al (2012) ZEB1 drives prometastatic actin cytoskeletal remodeling by downregulating miR-34a expression. J Clin Investig 122(9):3170-3183. https://doi.org/10.1172/JCI63608

Alemar B, Izetti P, Gregório C, Macedo GS, Castro MAA, Osvaldt AB, Matte U, Ashton-Prolla P (2016) miRNA-21 and miRNA-34a are potential minimally invasive biomarkers for the diagnosis of pancreatic ductal adenocarcinoma. Pancreas 45(1):84-92. https:// doi.org/10.1097/MPA.0000000000000383

Ali S, Dubaybo H, Brand RE, Sarkar FH (2015) Differential expression of microRNAs in tissues and plasma co-exists as a biomarker for pancreatic cancer. J Cancer Sci Ther 7(11):336-346. https://doi. org/10.4172/1948-5956.1000372

Amirkhah R, Schmitz U, Linnebacher M, Wolkenhauer O, Farazmand A (2015) MicroRNA-mRNA interactions in colorectal cancer and their role in tumour progression. Genes Chromosomes Cancer 54(3):129-141. https://doi.org/10.1002/gcc.22231

Anđelković M, Djordjevic AB, Miljaković EA, Javorac D, Čolaković N, Oprić S, Petričević S, Granić M, Kotur-Stevuljević J, Antonijević B, Bulat Z (2021) Cadmium tissue level in women diagnosed with breast cancer-A case control study. Environ Res 199:111300. https://doi.org/10.1016/j.envres.2021.111300

Arisan ED, Rencuzogullari O, Freitas IL, Radzali S, Keskin B, Kothari A, Warford A, Uysal-Onganer P (2020) Upregulated Wnt-11 and miR-21 expression trigger epithelial mesenchymal transition in aggressive prostate cancer cells. Biology 9(3):52. https://doi.org/ 10.3390/biology9030052

Arumugam T, Ramachandran V, Fournier KF, Wang H, Marquis L, Abbruzzese JL et al (2009) Epithelial to mesenchymal transition contributes to drug resistance in pancreatic cancer. Cancer Res 69:5820-5828. https://doi.org/10.1158/0008-5472.CAN-08-2819

Babar IA, Czochor J, Steinmetz A, Weidhaas JB et al (2011) Inhibition of hypoxia-induced miR-155 radiosensitizes hypoxic lung cancer cells. Cancer Biol Ther 12(10):908-914. https://doi.org/10.4161/ cbt.12.10.17681

Bakirtzi K, Hatziapostolou M, Karagiannides I et al (2011) Neurotensin signaling activates microRNAs-21 and -155 and Akt, promotes tumour growth in mice, and is increased in human colon tumours. Gastroenterology 141(5):1749-1761. https://doi.org/10.1053/j. gastro.2011.07.038

Ballehaninna UK, Chamberlain RS (2013) Biomarkers for pancreatic cancer: promising new markers and options beyond $\mathrm{CA}$ 19-9. Tumour Biol 34(6):3279-3292. https://doi.org/10.1007/ s13277-013-1033-3

Bartel DP (2004) MicroRNAs: genomics, biogenesis, mechanism, and function. Cell 116(2):281-297. https://doi.org/10.1016/S00928674(04)00045-5

Bloomston M, Frankel WL, Petrocca F, Volinia S, Alder H, Hagan JP, Liu CG, Bhatt D, Taccioli C, Croce CM (2007) MicroRNA expression patterns to differentiate pancreatic adenocarcinoma from normal pancreas and chronic pancreatitis. JAMA 297(17):1901-1908. https://doi.org/10.1001/jama. 297.17.1901

Bortesi L, Pesci A, Bogina G, Castelli P, Zamboni G (2011) Ductal adenocarcinoma of the pancreas. Surg Pathol Clin. 4(2):487-521. https://doi.org/10.1016/j.path.2011.03.007

Brabletz S, Bajdak K, Meidhof S, Burk U, Niedermann G, Firat E, Wellner U, Dimmler A, Faller G, Schubert J et al (2011) The ZEB1/miR-200 feedback loop controls Notch signalling in cancer cells. EMBO J 30(4):770-782. https://doi.org/10.1038/emboj. 2010.349

Brabletz T, Kalluri R, Nieto MA, Weinberg RA (2018) EMT in cancer. Nat Rev Cancer 18(2):128-134. https://doi.org/10.1038/nrc. 2017.118

Buck E, Eyzaguirre A, Barr S, Thompson S, Sennello R, Young D et al (2007) Loss of homotypic cell adhesion by epithelial-mesenchymal transition or mutation limits sensitivity to epidermal growth factor receptor inhibition. Mol Cancer Ther 6(2):532-541. https://doi.org/10.1158/1535-7163. MCT-06-0462

Buha A, Wallace D, Matovic V et al (2017) Cadmium exposure as a putative risk factor for the development of pancreatic cancer: three different lines of evidence. Biomed Res Int 2017:1981837. https://doi.org/10.1155/2017/1981837

Buha A, Matovic V, Antonijevic B, Bulat Z, Curcic M, Renieri EA, Tsatsakis AM, Schweitzer A, Wallace D (2018) Overview of cadmium thyroid disrupting effects and mechanisms. Int J Mol Sci 19(5):1501. https://doi.org/10.3390/ijms19051501

Buha A, Jugdaohsingh R, Matovic V, Bulat Z, Antonijevic B, Kerns JG, Goodship A, Hart A, Powell JJ (2019) Bone mineral health is sensitively related to environmental cadmium exposure-experimental and human data. Environ Res 176:108539. https://doi.org/ 10.1016/j.envres.2019.108539

Buha A, Đukić-Ćosić D, Ćurčić M, Bulat Z, Antonijević B, Moulis JM, Goumenou M, Wallace D (2020) Emerging links between cadmium exposure and insulin resistance: human, animal, and cell study data. Toxics 8(3):63. https://doi.org/10.3390/toxic s8030063

Burk U, Schubert J, Wellner U, Schmalhofer O, Vincan E, Spaderna S, Brabletz T (2008) A reciprocal repression between ZEB1 and members of the miR-200 family promotes EMT and invasion in cancer cells. EMBO Rep 9:582-589

Calatayud D, Dehlendorff C, Boisen MK, Hasselby JP, Schultz NA, Werner J, Immervoll H, Molven A, Hansen CP, Johansen JS (2017) Tissue MicroRNA profiles as diagnostic and prognostic biomarkers in patients with resectable pancreatic ductal adenocarcinoma and periampullary cancers. Biomark Res 5:e8. https:// doi.org/10.1186/s40364-017-0087-6

Chakraborty C, George Priya Doss C, Bandyopadhyay S (2013) miRNAs in insulin resistance and diabetes-associated pancreatic cancer: the "minute and miracle" molecule moving as a monitor in the "genomic galaxy." Curr Drug Targets United Arab Emirates 14(10):1110-1117. https://doi.org/10.2174/138945011131499 90182

Chan A et al (2014) Validation of biomarkers that complement ca19.9 in detecting early pancreatic cancer. Clin Cancer Res 20:5787-5795

Chang JC, Kundranda M (2017) Novel diagnostic and predictive biomarkers in pancreatic adenocarcinoma. Int J Mol Sci 18(3):e667. https://doi.org/10.3390/ijms18030667

Chen L, Xu B, Liu L, Luo Y, Zhou H, Chen W et al (2011) Cadmium induction of reactive oxygen species activates the mTOR pathway, leading to neuronal cell death. Free Radic Biol Med 50:624-632. https://doi.org/10.1016/j.freeradbiomed.2010.12. 032 
Chen Z, Pan T, Jiang D, Jin L, Geng Y, Feng X et al (2020) The lncRNA-GAS5/miR-221-3p/DKK2 axis modulates ABCB1mediated adriamycin resistance of breast cancer via the $\mathrm{Wnt} / \beta$ catenin signaling pathway. Mol Ther 19:1434-1448. https://doi. org/10.1016/j.omtn.2020.01.030

Dart DA, Arisan DE, Owen S, Hao C, Jiang WG, Uysal-Onganer P (2019) Wnt-11 expression promotes invasiveness and correlates with survival in human pancreatic ductal adenocarcinoma. Genes 10(11):921. https://doi.org/10.3390/genes10110921

De Craene B, Berx G (2013) Regulatory networks defining EMT during cancer initiation and progression. Nat Rev Cancer 13(2):97110. https://doi.org/10.1038/nrc3447

Dhayat SA, Abdeen B, Köhler G, Senninger N, Haier J, Mardin WA (2015) MicroRNA-100 and microRNA-21 as markers of survival and chemotherapy response in pancreatic ductal adenocarcinoma UICC stage II. Clin Epigenet 7:e132. https://doi.org/10.1186/ s13148-015-0166-1

Djordjevic VR, Wallace DR, Schweitzer A, Boricic N, Knezevic D, Matic S, Grubor N, Kerkez M, Radenkovic D, Bulat Z et al (2019) Environmental cadmium exposure and pancreatic cancer: evidence from case control, animal and in vitro studies. Environ Int 128:353-361. https://doi.org/10.1016/j.envint. 2019.04.048

Fathi M, Ghafouri-Fard S, Abak A, Taheri M (2021) Emerging roles of miRNAs in the development of pancreatic cancer. Biomed Pharmacother 141:111914. https://doi.org/10.1016/j.biopha. 2021.111914

Fedele M, Cerchia L, Chiappetta G (2017) The epithelial-to-mesenchymal transition in breast cancer: focus on basal-like carcinomas. Cancers 9(10):134. https://doi.org/10.3390/cancers9100134

Felipe Lima J, Nofech-Mozes S, Bayani J, Bartlett JMS (2016) EMT in breast carcinoma-a review. J Clin Med 5(7):65. https://doi. org $/ 10.3390 / \mathrm{jcm} 5070065$

Feng R et al (2010) miR-126 functions as a tumour suppressor in human gastric cancer. Cancer Lett 298:50-63

Feng H, Wang Y, Su J, Liang H, Zhang CY, Chen X, Yao W (2016) MicroRNA-148a suppresses the proliferation and migration of pancreatic cancer cells by down-regulating ErbB3. Pancreas 45(9):1263-1271. https://doi.org/10.1097/MPA.0000000000 000677

Garajová I, le Large TY, Frampton AE, Rolfo C, Voortman J, Giovannetti E (2014) Molecular mechanisms underlying the role of MicroRNAs in the chemoresistance of pancreatic cancer. BioMed Res Int 2014:1-17. https://doi.org/10.1155/2014/678401

Garofalo M, Quintavalle C, Di LG, Zanca C, Romano G, Taccioli C, Liu CG, Croce CM, Condorelli G (2008) MicroRNA signatures of TRAIL resistance in human non-small cell lung cancer. Oncogene 27(27):3845-3855. https://doi.org/10.1038/onc.2008.6

Gayral M, Jo S, Hanoun N, Vignolle-Vidoni A, Lulka H, Delpu Y, Meulle A, Dufresne M, Humeau M, Chalret du Rieu M et al (2014) MicroRNAs as emerging biomarkers and therapeutic targets for pancreatic cancer. World J Gastroenterol 20(32):11199_ 11209. https://doi.org/10.3748/wjg.v20.i32.11199

Gramantieri L, Fornari F, Ferracin M, Veronese A, Sabbioni S, Calin GA, Grazi GL, Croce CM, Bolondi L, Negrini M (2009) MicroRNA-221 targets Bmf in hepatocellular carcinoma and correlates with tumour multifocality. Clin Cancer Res 15(16):5073-5081. https://doi.org/10.1158/1078-0432.CCR-09-0092

Gregory PA, Bert AG, Paterson EL, Barry SC, Tsykin A, Farshid G, Vadas MA, Khew-Goodall Y, Goodall GJ (2008) The miR-200 family and miR-205 regulate epithelial to mesenchymal transition by targeting ZEB1 and SIP1. Nat Cell Biol 10(5):593-601. https://doi.org/10.1038/ncb1722

Greither T et al (2010) Elevated expression of microRNAs 155, 203, 210 and 222 in pancreatic tumours is associated with poorer survival. Int J Cancer 126(1):73-80. https://doi.org/10.1002/ijc. 24687

Grutzmann R (2004) ADAM9 expression in pancreatic cancer is associated with tumour type and is a prognostic factor in ductal adenocarcinoma. Br J Cancer 90(5):1053-1058. https://doi.org/ 10.1038/sj.bjc.6601645

Guo X, Wang XF (2009) Signaling cross-talk between TGF-beta/BMP and other pathways. Cell Res 19(1):71-88. https://doi.org/10. 1038/cr.2008.302

Hamada S, Satoh K, Miura S, Hirota M, Kanno A, Masamune A, Kikuta K, Kume K, Unno J, Egawa S et al (2013) miR-197 induces epithelial-mesenchymal transition in pancreatic cancer cells by targeting p120 catenin. J Cell Physiol 228(6):1255-1263. https://doi.org/10.1002/jcp. 24280

Harazono Y, Muramatsu T, Endo H, Uzawa N, Kawano T, Harada K, Inazawa J, Kozaki K (2013) miR-655 Is an EMT-suppressive microRNA targeting ZEB1 and TGFBR2. PLoS ONE 8(5):e62757. https://doi.org/10.1371/journal.pone.0062757

Hidalgo $\mathrm{M}$ et al (2015) Addressing the challenges of pancreatic cancer: future directions for improving outcomes. Pancreatology 15(1):8-18. https://doi.org/10.1016/j.pan.2014.10.001

Hong SM, Li A, Olino K, Wolfgang CL, Herman JM, Schulick RD, Iacobuzio-Donahue C, Hruban RH, Goggins M (2011) Loss of E-cadherin expression and outcome among patients with resectable pancreatic adenocarcinoma. Mod Pathol 24:1237-1247. https://doi.org/10.1038/modpathol.2011.74

Hotz B, Arndt M, Dullat S, Bhargava S, Buhr HJ, Hotz HG (2007) Epithelial to mesenchymal transition: expression of the regulators snail, slug, and twist in pancreatic cancer. Clin Cancer Res 13:4769-4776. https://doi.org/10.1158/1078-0432.CCR-06-2926

Hugo H, Ackland ML, Blick T, Lawrence MG, Clements JA, Williams ED (2007) Epithelial-mesenchymal and mesenchymal-epithelial transitions in carcinoma progression. J Cell Physiol 213(2):374383. https://doi.org/10.1002/jcp. 21223

Humphries B, Yang C (2015) The microRNA-200 family: small molecules with novel roles in cancer development, progression and therapy. Oncotarget 6(9):6472-6498. https://doi.org/10.18632/ oncotarget.3052

Iacobuzio-Donahue CA, Fu B, Yachida S, Luo M, Abe H, Henderson CM, Vilardell F, Wang Z, Keller JW, Banerjee P et al (2009) DPC4 gene status of the primary carcinoma correlates with patterns of failure in patients with pancreatic cancer. J Clin Oncol 27(11):1806-1813. https://doi.org/10.1200/JCO.2008.17.7188

Jiang N, Jiang X, Chen Z, Song X, Wu L, Zong D, Song D, Yin L, Wang D, Chen C et al (2017) MiR-203a-3p suppresses cell proliferation and metastasis through inhibiting LASP1 in nasopharyngeal carcinoma. J Exp Clin Cancer Res 36(1):e138. https://doi. org/10.1186/s13046-017-0604-3

Jiao LR, Frampton AE, Jacob J, Pellegrino L, Krell J, Giamas G, Tsim N, Vlavianos P, Cohen P, Ahmad R et al (2012) MicroRNAs targeting oncogenes are down-regulated in pancreatic malignant transfor-mation from benign tumours. PLoS ONE 7:e32068. https://doi.org/10.1371/journal.pone.0032068

Kalluri R, Weinberg RA (2009) The basics of epithelial mesenchymal transition. J Clin Invest 119(2009):1420-1428. https://doi.org/ 10.1172/JCI39104

Khakinezhad Tehrani F, Ranji N, Kouhkan F, Hosseinzadeh S (2021) PANC-1 cancer stem-like cell death with silybin encapsulated in polymersomes and deregulation of stemness-related miRNAs and their potential targets. Iranian J Basic Med Sci 24(4):514-523. https://doi.org/10.22038/ijbms.2021.54001.12136

Komoto M, Nakata B, Amano R, Yamada N, Yashiro M, Ohira M, Wakasa K, Hirakawa K (2009) HER2 overexpression correlates with survival after curative resection of pancreatic cancer. Cancer Sci 100(7):1243-1247. https://doi.org/10.1111/j.1349-7006. 2009.01176.x 
Krebs AM, Mitschke J, Lasierra Losada M, Schmalhofer O, Boerries $\mathrm{M}$, Busch $\mathrm{H}$, Boettcher $\mathrm{M}$, Mougiakakos D, Reichardt W, Bronsert P et al (2017) The EMT-activator Zeb1 is a key factor for cell plasticity and promotes metastasis in pancreatic cancer. Nat Cell Biol 19(5):518-529. https://doi.org/10.1038/ncb3513

Lamouille S, Xu J, Derynck R (2014) Molecular mechanisms of epithelial-mesenchymal transition. Nat Rev Mol Cell Biol 15(3):178196. https://doi.org/10.1038/nrm3758

Lee TK, Poon RTP, Yuen AP, Ling MT, Kwok WK, Wang XH (2006) Twist overexpression correlates with hepatocellular carcinoma metastasis through induction of epithelial-mesenchymal transition. Clin Cancer Res 12(18):5369-5376. https://doi.org/10. 1158/1078-0432.ccr-05-2722

Li QQ, Xu JD, Wang WJ et al (2009) Twist1-mediated adriamycininduced epithelial-mesenchymal transition relates to multidrug resistance and invasive potential in breast cancer cells. Clin Cancer Res 15(8):2657-2665. https://doi.org/10.1158/1078-0432. CCR-08-2372

Li A, Omura N, Hong SM, Vincent A, Walter K, Griffith M, Borges M, Goggins M (2010) Pancreatic cancers epigenetically silence SIP1 and hypomethylate and overexpress miR-200a/200b in association with elevated circulating miR-200a and miR-200b levels. Cancer Res 70(13):5226-5237. https://doi.org/10.1158/ 0008-5472.CAN-09-4227

Lima RT, Busacca S, Almeida GM, Gaudino G, Fennell DA, Vasconcelos MH (2011) MicroRNA regulation of core apoptosis pathways in cancer. Eur J Cancer 47(2):163-174. https://doi.org/10.1016/j. ejca.2010.11.005

Lin S, Gregory RI (2015) MicroRNA biogenesis pathways in cancer. Nat Rev Cancer 15:321-333. https://doi.org/10.1038/nrc3932

Lin K, Baritaki S, Militello L, Malaponte G, Bevelacqua Y, Bonavida B (2010) The role of B-RAF mutations in melanoma and the induction of EMT via dysregulation of the NF- B/Snail/RKIP/ PTEN Circuit. Genes Cancer 1(5):409-420. https://doi.org/10. $1177 / 1947601910373795$

Liu J, Qu W, Kadiiska MB (2009) Role of oxidative stress in cadmium toxicity and carcinogenesis. Toxicol Appl Pharmacol 238:209214. https://doi.org/10.1016/j.taap.2009.01.029

Liu M, Liu J, Wang L, Wu H, Zhou C, Zhu H, Xu N, Xie Y (2014) Association of serum microRNA expression in hepatocellular carcinomas treated with transarterial chemoembolization and patient survival. PLoS ONE 9(10):e109347. https://doi.org/10. 1371/journal.pone.0109347

Liu Q, Zheng C, Shen H, Zhou Z, Lei Y (2015) MicroRNAs-mRNAs expression profile and their potential role in malignant transformation of human bronchial epithelial cells induced by cadmium. BioMed Res Int 2015:902025. https://doi.org/10.1155/ 2015/902025

Lu X, Zhao P, Zhang C, Fu Z, Chen Y, Lu A, Liu N, You Y, Pu P, Kang C (2009) Analysis of miR-221 and p27 expression in human gliomas. Mol Med Rep 2(4):651-656. https://doi.org/10.3892/ mmr_00000152

Lu Y, Ji N, Wei W, Sun W, Gong X, Wang X (2017) MiR-142 modulates human pancreatic cancer proliferation and invasion by targeting hypoxia-inducible factor $1(\mathrm{HIF}-1 \alpha)$ in the tumour microenvironments. Biol Open 6(2):252-259

Maier HJ, Schmidt-Strassburger U, Huber MA, Wiedemann EM, Beug H, Wirth T (2010) NF-kappaB promotes epithelial-mesenchymal transition, migration and invasion of pancreatic carcinoma cells. Cancer Lett 295(2):214-228. https://doi.org/10.1016/j. canlet.2010.03.003

Martinez-Zamudio R, Ha HC (2011) Environmental epigenetics in metal exposure. Epigenetics 6(7):820-827. https://doi.org/10. 4161/epi.6.7.16250

Masamune A, Nakano E, Hamada S, Takikawa T, Yoshida N, Shimosegawa $\mathrm{T}$ (2013) Alteration of the microRNA expression profile during the activation of pancreatic stellate cells. Scand J Gastroenterol 49(3):323-331. https://doi.org/10.3109/00365 521.2013 .876447

McCubrey JA, Fitzgerald TL, Yang LV, Lertpiriyapong K, Steelman LS, Abrams SL, Montalto G, Cervello M, Neri LM, Cocco L et al (2016) Roles of GSK-3 and microRNAs on epithelial mesenchymal transition and cancer stem cells. Oncotarget 8(8):1422114250. https://doi.org/10.18632/oncotarget. 13991

Meltzer PS (2005) Cancer genomics: small RNAs with big impacts. Nature 435:745-746. https://doi.org/10.1038/435745a

Mercatelli N, Coppola V, Bonci D, Miele F, Costantini A, Guadagnoli M, Bonanno E, Muto G, Frajese GV, De Maria R, Spagnoli LG, Farace MG, Ciafre SA (2008) The inhibition of the highly expressed miR-221 and miR-222 impairs the growth of prostate carcinoma xenografts in mice. PLoS ONE 3(12):e4029. https:// doi.org/10.1371/journal.pone.0004029

Mongroo PS, Rustgi AK (2010) The role of the miR-200 family in epithelial-mesenchymal transition. Cancer Biol Ther 10(3):219222. https://doi.org/10.4161/cbt.10.3.12548

Mortoglou M, Wallace D, Buha Djordjevic A, Djordjevic V, Arisan ED, Uysal-Onganer P (2021a) MicroRNA-regulated signaling pathways: potential biomarkers for pancreatic ductal adenocarcinoma. Stresses 1(1):30-47. https://doi.org/10.3390/stresses 10 10004

Mortoglou M, Tabina ZK, Arisan ED, Kocher HM, Uysal-Onganer P (2021b) Non-coding RNAs in pancreatic ductal adenocarcinoma: new approaches for better diagnosis and therapy. Translational Oncology 14(7):101090. https://doi.org/10.1016/j.tranon.2021. 101090

Mou T, Zhu D, Wei X, Li T, Zheng D, Pu J et al (2017) Identification and interaction analysis of key genes and microRNAs in hepatocellular carcinoma by bioinformatics analysis. World J Surg Oncol 15(1):1-9. https://doi.org/10.1186/s12957-017-1127-2

Murillo-Garzón V, Gorroño-Etxebarria I, Åkerfelt M, Puustinen MC, Sistonen L, Nees M, Carton J, Waxman J, Kypta RM (2018) Frizzled- 8 integrates Wnt- 11 and transforming growth factor- $\beta$ signaling in prostate cancer. Nat Commun 9(1):1747. https://doi. org/10.1038/s41467-018-04042-w

Nakamura M, Tokura Y (2011) Epithelial-mesenchymal transition in the skin. J Dermatol Sci 61(1):7-13. https://doi.org/10.1016/j. jdermsci.2010.11.015

Ngalame NNO, Waalkes MP, Tokar EJ (2016) Silencing KRAS Overexpression in Cadmium-Transformed Prostate Epithelial Cells Mitigates Malignant Phenotype. Chem Res Toxicol 29:1458-1467

Nikiforova MN, Tseng GC, Steward D et al (2008) MicroRNA expression profiling of thyroid tumours: biological significance and diagnostic utility. J Clin Endocrinol Metab 93(5):1600-1608. https://doi.org/10.1210/jc.2007-2696

Otsuka K, Ochiya T (2014) Genetic networks lead and follow tumour development: microRNA regulation of cell cycle and apoptosis in the p53 pathways. Biomed Res Int. https://doi.org/10.1155/ 2014/749724

Ouyang H, Gore J, Deitz S, Korc M (2014) microRNA-10b enhances pancreatic cancer cell invasion by suppressing TIP30 expression and promoting EGF and TGF- $\beta$ actions. Oncogene 33(38):46644674. https://doi.org/10.1038/onc.2013.405

Papaconstantinou IG et al (2013) Expression of microRNAs in patients with pancreatic cancer and its prognostic significance. Pancreas 42(1):67-71. https://doi.org/10.1097/MPA.0b013e3182592ba7

Park J-K, Lee EJ, Esau C, Schmittgen TD (2009) Antisense inhibition of microRNA-21 or -221 arrests cell cycle, induces apoptosis, and sensitizes the effects of gemcitabine in pancreatic adenocarcinoma. Pancreas 38(7):e190-e199. https://doi.org/10.1097/ MPA.0b013e3181ba82e1 
Pellegrini KL, Gerlach CV, Craciun FL, Ramachandran K, Bijol V, Kissick HT, Vaidya VS (2016) Application of small RNA sequencing to identify microRNAs in acute kidney injury and fibrosis. Toxicol Appl Pharmacol 312:42-52

Peng L, Liu Z, Xiao J, Tu Y, Wan Z, Xiong H, Li Y, Xiao W (2017) MicroRNA-148a suppresses epithelial-mesenchymal transition and invasion of pancreatic cancer cells by targeting Wnt10b and inhibiting the $\mathrm{Wnt} / \beta$-catenin signaling pathway. Oncol Rep 38(1):301-308. https://doi.org/10.3892/or.2017.5705

Peter ME (2009) Let-7 and miR-200 microRNAs: guardians against pluripotency and cancer progression. Cell Cycle 8:843-852

Piasecka D, Braun M, Kordek R, Sadej R, Romanska H (2018) MicroRNAs in regulation of triple-negative breast cancer progression. J Cancer Res Clin Oncol 144(8):1401-1411. https://doi.org/10. 1007/s00432-018-2689-2

Ribatti D, Tamma R, Annese T (2020) Epithelial-mesenchymal transition in cancer: a historical overview. Translational Oncology 13(6):100773. https://doi.org/10.1016/j.tranon.2020.100773

Roche J (2018) The epithelial-to-mesenchymal transition in cancer. Cancers 10(2):52. https://doi.org/10.3390/cancers10020052

Ryan DP, Hong TS, Bardeesy N (2014) Pancreatic adenocarcinoma. N Engl J Med 371(22):2140-2141. https://doi.org/10.1056/NEJMc 1412266

Ryu JK, Hong SM, Karikari CA, Hruban RH, Goggins MG, Maitra A (2010) Aberrant MicroRNA-155 expression is an early event in the multistep progression of pancreatic adenocarcinoma. Pancreatology 10(1):66-73. https://doi.org/10.1159/000231984

Sarkar S, Dubaybo H, Ali S, Goncalves P, Kollepara SL, Sethi S et al (2013) Down-regulation of miR-221 inhibits proliferation of pancreatic cancer cells through up-regulation of PTEN, p27(kip1), p57(kip2), and PUMA. Am J Cancer Res 3(5):465-477

Scara S, Bottoni P, Scatena R (2015) Ca 19-9: Biochemical and clinical aspects. Adv Exp Med Biol 867:247-260

Sempere LF et al (2010) Fluorescence-based codetection with protein markers reveals distinct cellular compartments for altered MicroRNA expression in solid tumours. Clin Cancer Res 16:4246-4255

Sethi S, Sethi S, Bluth MH (2018) Clinical implication of microRNAs in molecular pathology: an update for 2018. Clin Lab Med 38(2):237-251. https://doi.org/10.1016/j.cll.2018.02.003

Seton-Rogers S (2016) Epithelial-mesenchymal transition: untangling EMT's functions. Nat Rev Cancer 16(1):1. https://doi.org/10. 1038/nrc.2015.6

Siegel R, Ma J, Zou Z, Jemal A (2014) Cancer statistics. CA Cancer J Clin 64(1):9-29. https://doi.org/10.3322/caac.21208

Singh A, Settleman J (2010) EMT, cancer stem cells and drug resistance: an emerging axis of evil in the war on cancer. Oncogene 29(34):4741-4751. https://doi.org/10.1038/onc.2010.215

Słotwiński R, Lech G, Słotwińska SM (2018) MicroRNAs in pancreatic cancer diagnosis and therapy. CEJOI 43:314-324. https://doi.org/ 10.5114/ceji.2018.80051

Song Q, An Q, Niu B, Lu X, Zhang N, Cao X (2019) Role of miR$221 / 222$ in tumour development and the underlying mechanism. J Oncol. https://doi.org/10.1155/2019/7252013

Stemmler MP, Eccles RL, Brabletz S, Brabletz T (2019) Non-redundant functions of EMT transcription factors. Nat Cell Biol 21(1):102112. https://doi.org/10.1038/s41556-018-0196-y

Su A, He S, Tian B, Hu W, Zhang Z (2013) MicroRNA-221 mediates the effects of PDGF-BB on migration, proliferation, and the epithelial-mesenchymal transition in pancreatic cancer cells. PLoS ONE 8:e71309. https://doi.org/10.1371/journal.pone.0071309

Szafranska AE, Davison TS, John J et al (2007) MicroRNA expression alterations are linked to tumourigenesis and non-neoplastic processes in pancreatic ductal adenocarcinoma. Oncogene 26(30):4442-4452. https://doi.org/10.1038/sj.onc.1210228
Tan X, Banerjee P, Guo HF, Ireland S, Pankova D, Ahn Y, Nikolaidis IM, Liu X, Zhao Y, Xue Y et al (2017) Epithelial-to-mesenchymal transition drives a pro-metastatic Golgi compaction process through scaffolding protein PAQR11. J Clin Investig 127(1):117131. https://doi.org/10.1172/JCI88736

Tan X, Banerjee P, Liu X, Yu J, Gibbons DL, Wu P, Scott KL, Diao L, Zheng X, Wang J et al (2018) The epithelial-to-mesenchymal transition activator ZEB1 initiates a prometastatic competing endogenous RNA network. J Clin Investig 128(4):1267-1282. https://doi.org/10.1172/JCI97225

Tang J, Li Y, Wang J, Wen Z, Lai M, Zhang H (2016) Molecular mechanisms of microRNAs in regulating epithelial-mesenchymal transitions in human cancers. Cancer Lett 371(2):301-313. https://doi.org/10.1016/j.canlet.2015.11.043

Tang Y, Cheng TY, YS, (2017) miR-34a inhibits pancreatic cancer progression through Snaill-mediated epithelial-mesenchymal transition and the Notch signaling pathway. Sci Rep 7:e38232. https://doi.org/10.1038/srep38232

Tao K, Yang J, Guo Z, Hu Y, Sheng H, Gao H, Yu H (2014) Prognostic value of mir-221-3p, mir-342-3p and mir-491-5p expression in colon cancer. Am J Transl Res 6(4):391-401

Urani C, Melchioretto P, Fabbri M, Bowe G, Maserati E, Gribaldo L (2014) Cadmium impairs p53 activity in HepG2 cells. ISRN Toxicol 2014:976428

Uysal-Onganer P, Kawano Y, Caro M et al (2010) Wnt-11 promotes neuroendocrine-like differentiation, survival and migration of prostate cancer cells. Mol Cancer 9:55. https://doi.org/10.1186/ 1476-4598-9-55

Uysal-Onganer P, D’Alessio S, Mortoglou M, Kraev I, Lange S (2021) Peptidylarginine deiminase inhibitor application, using Cl-Amidine, PAD2, PAD3 and PAD4 isozyme-specific inhibitors in pancreatic cancer cells, reveals roles for PAD2 and PAD3 in cancer invasion and modulation of extracellular vesicle signatures. Int J Mol Sci 22(3):1396. https://doi.org/ 10.3390/ijms22031396

Vega S, Morales AV, Ocaña OH, Valdés F, Fabregat I, Nieto MA (2004) Snail blocks the cell cycle and confers resistance to cell death. Genes Dev 18(10):1131-1143. https://doi.org/10.1101/ gad.294104

Von Hoff DD, Korn R, Mousses S (2009) Pancreatic cancer-could it be that simple? A different context of vulnerability. Cancer Cell 16(1):7-8. https://doi.org/10.1016/j.ccr.2009.06.011

Waisberg M, Joseph P, Hale B, Beyersmann D (2003) Molecular and cellular mechanisms of cadmium carcinogenesis. Toxicology 192:95-117. https://doi.org/10.1016/S0300-483X(03)00305-6

Wallace DR, Spandidos DA, Tsatsakis A, Schweitzer A, Djordjevic V, Djordjevic AB (2019) Potential interaction of cadmium chloride with pancreatic mitochondria: implications for pancreatic cancer. Int J Mol Med 44(1):145-156. https://doi.org/10.3892/ ijmm.2019.4204

Wallace DR, Taalab YM, Heinze S, Tariba Lovaković B, Pizent A, Renieri E, Tsatsakis A, Farooqi AA, Javorac D, Andjelkovic M, Bulat Z, Antonijević B, Buha Djordjevic A (2020) Toxic-metalinduced alteration in miRNA expression profile as a proposed mechanism for disease development. Cells 9(4):901. https://doi. org/10.3390/cells9040901

Wang X, Liu D, Zhou K, Wang B, Liu Q, Deng F, Li Q, Ma Y (2016) Expression of Wnt-11 and Rock2 in esophageal squamous cell carcinoma by activation of the WNT/PCP pathway and its clinical significance. Pathol Res Pract 212(10):880-885. https://doi. org/10.1016/j.prp.2016.07.008

Wang S, Huang S, Sun YL (2017) Epithelial-mesenchymal transition in pancreatic cancer: a review. Biomed Res Int 2017:2646148. https://doi.org/10.1155/2017/2646148

Wang L, Yao M, Fang M, Zheng WJ, Dong ZZ, Pan LH, Zhang HJ, Yao DF (2018a) Expression of hepatic Wnt5a and its 
clinicopathological features in patients with hepatocellular carcinoma. Hepatobiliary Pancreat Dis Int 17(3):227-232. https:// doi.org/10.1016/j.hbpd.2018.03.005

Wang W, Chen J, Luo L, Li Y, Liu J, Zhang W (2018b) Effect of cadmium on kitl pre-mRNA alternative splicing in murine ovarian granulosa cells and its associated regulation by miRNAs. J Appl Toxicol 38:227-239

Wei H, Wang N, Zhang Y, Wang S, Pang X, Zhang J, Luo Q, Su Y, Zhang S (2014) Clinical significance of Wnt-11 and squamous cell carcinoma antigen expression in cervical cancer. Med Oncol 31(5):933. https://doi.org/10.1007/s12032-014-0933-4

Wei C, Xiang S, Yu Y, Song J, Zheng M, Lian F (2021) miR-221-3p regulates apoptosis of ovarian granulosa cells via targeting FOXO1 in older women with diminished ovarian reserve (DOR). Mol Reprod Dev 88(4):251-260. https://doi.org/10.1002/mrd. 23457

Winter JM, Ting AH, Vilardell F, Gallmeier E, Baylin SB, Hruban RH, Kern SE, Iacobuzio-Donahue CA (2008) Absence of E-cadherin expression distinguishes noncohesive from cohesive pancreatic cancer. Clin Cancer Res 14(2):412-418. https://doi.org/10.1158/ 1078-0432.CCR-07-0487

Winter JM, Yeo CJ, Brody JR (2013) Diagnostic, prognostic, and predictive biomarkers in pancreatic cancer. J Surg Oncol 107(1):1522. https://doi.org/10.1002/jso.23192

Xu Q et al (2015) miR-221/222 induces pancreatic cancer progression through the regulation of matrix metalloproteinases. Oncotarget 6(16): 14153-14164

Yamakuchi M (2012) MicroRNA regulation of SIRT1. Front Physiol 3:1-8. https://doi.org/10.3389/fphys.2012.00068

Yang W, Yang Y, Xia L, Yang Y, Wang F, Song M, Chen X, Liu J, Song Y, Zhao Y et al (2016) MiR-221 Promotes Capan-2 Pancreatic Ductal Adenocarcinoma Cells Proliferation by Targeting PTENAkt. Cell Physiol Biochem 38(6):2366-2374. https://doi.org/10. $1159 / 000445589$

Yang H, Wang L, Tang X, Bai W (2017) miR-203a suppresses cell proliferation by targeting E2F transcription factor 3 in human gastric cancer. Oncol Lett 14(6):7687-7690. https://doi.org/10. 3892/ol.2017.7199

Yau TO, Wu CW, Dong Y, Tang CM, Ng SSM, Chan FKL, Sung JJY, Yu J (2014) microRNA-221 and microRNA-18a identification in stool as potential biomarkers for the non-invasive diagnosis of colorectal carcinoma. Br J Cancer 111:1765-1771. https://doi. org/10.1038/bjc.2014.484

Ye X, Brabletz T, Kang Y, Longmore GD, Nieto MA, Stanger BZ, Yang J, Weinberg RA (2017) Upholding a role for EMT in breast cancer metastasis. Nat Cell Biol 547(7661):e1-e3. https://doi. org/10.1038/nature22816

Yin T, Wang C, Liu T, Zhao G, Zha Y, Yang M (2007) Expression of Snail in pancreatic cancer promotes metastasis and chemoresistance. J Surg Res 141(2):196-203. https://doi.org/10.1016/j.jss. 2006.09.027

Yu J, Ohuchida K, Mizumoto K, Sato N, Kayashima T, Fujita H, Nakata K, Tanaka M (2010) MicroRNA, hsa-miR-200c, is an independent prognostic factor in pancreatic cancer and its upregulation inhibits pancreatic cancer invasion but increases cell proliferation. Mol Cancer 9:169

$\mathrm{Yu} \mathrm{J}$ et al (2012) MicroRNA alterations of pancreatic intraepithelial neoplasias. Clin Cancer Res 18(4):981-992. https://doi.org/10. 1158/1078-0432.CCR-11-2347

Zhang Y, Li M, Wang H, Fisher WE, Lin PH, Yao Q, Chen C (2008) Profiling of 95 MicroRNAs in Pancreatic Cancer Cell Lines and Surgical Specimens by Real-Time PCR Analysis. World J Surg 33(4):698-709. https://doi.org/10.1007/s00268-008-9833-0

Zhang C, Kang C, You Y, Pu P, Yang W, Zhao P, Wang G, Zhang A, Jia Z, Han L, Jiang H (2009) Co-suppression of miR-221/222 cluster suppresses human glioma cell growth by targeting p27kip1 in vitro and in vivo. Int J Oncol 34(6):1653-1660. https://doi. org/10.3892/ijo_00000296

Zhang C, Zhang J, Hao J, Shi Z, Wang Y, Han L, Yu S, You Y, Jiang T, Wang J, Liu M, Pu P, Kang C (2012) High level of miR-221/222 confers increased cell invasion and poor prognosis in glioma. $\mathrm{J}$ Transl Med 10:119. https://doi.org/10.1186/1479-5876-10-119

Zheng Q, Peskoe SB, Ribas J, Rafiqi F, Kudrolli T, Meeker AK, de Marzo AM, Platz EA, Lupold SE (2014) Investigation of mir21, mir-141, and mir-221 expression levels in prostate adenocarcinoma for associated risk of recurrence after radical prostatectomy. Prostate 74(16):1655-1662. https://doi.org/10.1002/ pros. 22883

Zhou X et al (2016) A panel of 13-miRNA signature as a potential biomarker for predicting survival in pancreatic cancer. Oncotarget 7(43):69616-69624. https://doi.org/10.18632/oncotarget.11903

Publisher's Note Springer Nature remains neutral with regard to jurisdictional claims in published maps and institutional affiliations. 